
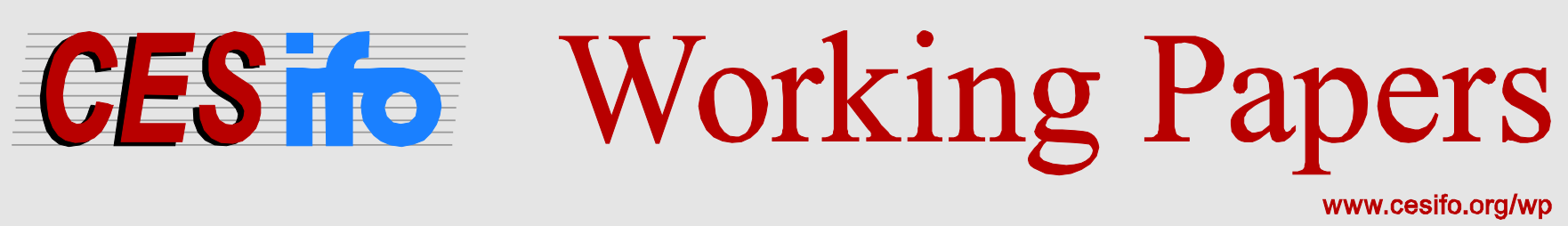

\title{
Using Political Financing Reforms to Measure Campaign Spending Effects on Electoral Outcomes
}

\author{
Abel François \\ Michael Visser \\ Lionel Wilner
}

CESIFO WORKING PAPER NO. 6232

CATEgory 2: Public CHOICE

DECEMBER 2016
An electronic version of the paper may be downloaded
- from the SSRN website: Www.SSRN.com
- from the RePEc website: Www.RePEc.org
- from the CESifo website: www.CESifo-group.org/wp




\title{
Using Political Financing Reforms to Measure Campaign Spending Effects on Electoral Outcomes
}

\begin{abstract}
This paper studies the impact of campaign spending on votes in French legislative elections. We exploit the political financing reforms which were adopted in France in the mid-1990s. Under the new laws, spending limits were reduced, legal persons were no longer allowed to finance candidates, and the maximal amount of personal expenditures reimbursed by the State was augmented. We have data on two consecutive elections (one before and one after the reforms) and focus on candidates who competed in both of them. We find that the difference in candidates' campaign expenses across elections is strongly affected by the reforms. We then estimate a structural vote equation using panel data to control for unobserved characteristics of candidates. Spending has a statistically significant effect, but only for challengers. We cannot reject the hypothesis that challenger spending has the same impact across the various political parties in France.
\end{abstract}

JEL-Codes: C230, D720.

Keywords: campaign spending, elections, political financing reforms.

\author{
Abel François \\ University of Lille 1 \\ France - 59655 Villeneuve d'Ascq Cedex \\ abel.francois@univ-lille1.fr
}

\author{
Michael Visser \\ CREST ( ENSAE) \& CRED \\ University of Paris 2 \\ Paris / France \\ michael.visser@ensae.fr
}

\author{
Lionel Wilner \\ CRES (ENSAE) \\ Paris / France \\ lionel.wilner@ensae.fr
}

November 29, 2016

We thank Xavier D’Haultfoeuille, Laurent Davezies, Francis Kramarz, Laurent Linnemer, Christian Ochsner, Alois Stutzer, and seminar participants at CREST, the University of Paris 2 (CRED), the International Association for Applied Econometrics conference in London, the European Economic Association congress in Toulouse, the American Law and Economics Association meeting in Boston, and the CESifo workshop on political economy in Dresden, for helpful comments and suggestions. 


\section{Introduction}

The relationship between campaign spending and election outcomes has always been a hotly debated topic in both the media and the academic world. Press articles and radio programs abound with stories about the huge amounts of campaign money collected by some political candidates, and the presumed impact of these large sums on electoral success. Social scientists have extensively studied the subject over the past few decades. ${ }^{1}$ From the beginning this literature has acknowledged the fundamental problem in establishing a causal link between spending and votes, namely the problem that campaign money is potentially an endogenous variable in vote regression functions. This endogeneity can be a consequence of simultaneity since it is likely that the two variables are jointly determined: the number of votes received by candidates is a function of campaign spending, but spending itself is likely to depend on (expected) vote outcomes. Endogeneity can also arise when there are hidden characteristics of candidates and electoral districts that determine both vote outcomes and spending levels, resulting in a classical omitted-variable bias when standard estimation methods are used.

Most papers have tried to circumvent the endogeneity bias by adopting an instrumental variable (IV) approach. Jacobson (1978), for instance, instrumented challenger's spending by challenger's party and district party strength, and incumbent's spending by a dummy variable indicating whether the incumbent ran in a primary election. Gerber (1998) used instead the wealth of candidates as instruments for spending, and Rekkas (2007) the lagged campaign spending at the constituency level. Foucault and François (2005) and Milligan and Rekkas (2008) instrumented the endogenous variable by the spending limit in each constituency. Unfortunately, relatively little consensus has emerged from these studies. The IV-based literature has produced very different and conflicting empirical results, and the IVs themselves have been the subject of much criticism from other researchers. This has raised skepticism about the possibility to find credible IVs and led some academics to call for alternative approaches. For instance, Jacobson (2006) argues that "it has become increasingly clear that progress on the question requires new research strategies. [...] Despite more than 20 years of research, we still have plenty to learn."

One alternative identification strategy to uncover the causal effect of spending has been proposed by Levitt (1994). He studies U.S. House elections in which the same two

\footnotetext{
${ }^{1}$ The large majority of this literature analyzes data from the U.S. on elections for the House of Representatives or the Senate. See, for example, Glantz, Abramowitz, and Burkart (1976), Jacobson (1978), Welch (1981), Abramowitz (1988), Abramowitz (1991), Levitt (1994), Erikson and Palfrey (1998), and Gerber (1998). Some examples of studies based on elections outside the U.S. are Rekkas (2007) and Milligan and Rekkas (2008) (Canadian federal elections), Pattie, Johnston, and Fieldhouse (1995) (British general elections), Cox and Thies (2000) (Japanese House elections), Da Silveira and De Mello (2011) (gubernatorial elections in Brazil), Durante and Gutierrez (2014) (Mexican presidential elections), and Palda and Palda (1998) and Foucault and François (2005) (French National Assembly elections).
} 
candidates competed with each other on multiple occasions. By regressing differences in votes on differences in spending levels, the unobserved candidate characteristics that are constant across elections are eliminated. Such first difference estimates of the effect of spending thus eliminate the bias due to omitted fixed unobservable variables.

Yet another alternative strategy is proposed in a series of recent papers and consists in using field or natural experiments. Da Silveira and De Mello (2011) exploit a natural experiment to analyze the influence of TV advertising on elections of governors in Brazil. They obtain identification by using the fact that, in the first round of gubernatorial elections, candidates' TV advertising shares are determined by their coalitions' share of seats in the National Parliament (the two candidates who make it to the second round equally share TV advertising time). Durante and Gutierrez (2014) also make use of a natural experiment. They estimate the effect of TV and radio advertising on vote intentions during presidential elections in Mexico. The variation of voters' exposure to political advertising is exogenous since the time of the day at which campaign spots of the different parties are aired is randomly assigned. Gerber, Gimpel, Green, and Shaw (2011) organized a field experiment designed to investigate the impact of political advertising on vote intentions in a gubernatorial election in Texas. The causal effects are identified in this paper because the launch date and volume of advertising in the different experimental markets are randomly determined.

Our paper contributes to this recent branch of the literature. We analyze the effect of campaign spending on votes obtained by candidates in French legislative elections. We have data on two successive elections, the ones held in 1993 and 1997. For both elections we observe the characteristics of candidates (party affiliations, incumbency status, and whether local political mandates were held), the number of votes they obtained, the amount of money spent on campaigning, and, quite unusually, the sources of campaign spending (amounts of money donated to candidates by parties, by voters, and by legal persons; amount financed by candidates themselves).

We take benefit of several important reforms which were introduced between the two elections. The reforms were adopted following several highly mediatized scandals in the 1980s involving a series of kickback schemes and excessive campaign contributions from the private sector. Three major changes were implemented. First, the spending limit was reduced in each electoral constituency. Second, legal persons (firms, corporations, unions, etc.) were no longer allowed to finance the campaigns of political candidates. Third, to compensate for the absence of funding from legal persons, the maximal reimbursable amount of personal contributions from candidates was increased from 10 to $50 \%$ of the spending limit in each constituency.

These campaign financing reforms can be seen as a natural experiment that led to 
considerable changes in spending patterns between 1993 and $1997 .{ }^{2}$ For candidates who competed in both elections we show that the observed changes in spending levels are largely driven by the new reforms. Those from the moderate left and moderate right were clearly hurt by the new laws. For many of them the expenses in 1993 were close to the spending limit prevailing in that election, and hence they were affected by the first law reform. These candidates were also generously financed by legal persons in 1993, a source of financing on which they could no longer rely in 1997 because of the second reform. Although many increased their personal contributions between 1993 and 1997 (they benefitted from the third reform), the overall spending levels of these types of candidates strongly decreased between the two elections. On the other hand, the reforms favored candidates from the far-left and far-right. These candidates received little or nothing from legal persons in 1993, but considerably augmented their personal expenditures in 1997 . The difference in candidates' expenditures across the two elections appears therefore to be mainly due to institutional modifications, and not the consequence of choices made by the candidates themselves.

To estimate the effect of campaign spending we use a standard model introduced by Berry (1994). In this framework, consumers face a number of differentiated products in the market and purchase the one that maximizes their utility (they may also decide not to purchase at all, i.e., choose the outside option). The framework can straightforwardly be applied to an electoral setting by letting voters play the role of consumers, candidates the role of products, and electoral districts the role of markets. The outside option in an electoral setting corresponds to not voting for any of the candidates, and the total market size is the number of individuals who registered for the election. The resulting vote share of a candidate (the analogue of the product market share) divided by the share of the outside option only depends on the characteristics of that candidate including spending. This renders a framework à la Berry particularly well adapted to our setting since there are multiple candidates competing with each other in French legislative elections (unlike most U.S. elections that have been studied in the literature and which are typically twocandidate elections). Rekkas (2007) was the first to adopt this kind of framework to analyze the determinants of election outcomes. She applied it in an analysis of a single election (the 1997 Canadian federal election). We will use the framework to analyze two subsequent elections.

In the same spirit as Levitt (1994), we use the sample of candidates present in both elections and estimate the parameters of interest using the first-difference estimation method. A first-difference transformation of the vote share equation allows in particular to get rid of the effect of unobserved candidate-specific variables that are fixed across time, and the only

\footnotetext{
${ }^{2}$ Palda and Palda (1998) and Foucault and François (2005), the only available papers on French data, have analyzed the legislative elections of 1993 and 1997, respectively. They do not, however, exploit the financing reforms introduced between these two elections like we do.
} 
requirement for the estimator to be unbiased is that the difference in the error terms of the transformed vote equation is mean independent of the difference in spending levels. Given that the spending difference is primarily determined by the law reforms, it seems reasonable to make this exogeneity assumption. ${ }^{3}$ Our estimation results indicate that spending has a statistically significant effect only for challengers, not for incumbents. We also estimate a specification of the model wherein the effect of challenger spending is allowed to differ by party (in France there are parties of the centre-left and centre-right, those from the far-left and far-right, and other small parties). We cannot reject, however, the hypothesis that the coefficients are equal.

Our paper is also related to a series of articles in which U.S. state-level changes in campaign finance laws are used to study the effects of regulating money in politics (see Stratmann (2005) for a survey). These articles have investigated the impact of contribution caps on lobby formation, the closeness of elections, and the number of candidates. They have also examined the impact of regulation on voter participation and political efficacy. However, this literature has so far not analyzed how law reforms change spending patterns, nor has it used modifications in campaign financing laws as a source to identify the spending effect.

Section 2 gives institutional background information about legislative elections in France and the political financing reforms, Section 3 describes the data, and Section 4 shows how the reforms affected the difference in spending levels across time. In Section 5 we present the structural model of voting behavior and the resulting vote equations. Section 6 presents the estimation results of the vote equations, and Section 7 concludes.

\section{Institutional background}

\subsection{Legislative elections in France}

The representatives of the French National Assembly (the lower house of the bicameral Parliament of France) are elected by direct universal suffrage. ${ }^{4}$ The Assembly is in principle renewed every five years, but the French President has the right to call an early election, i.e., before the five-year term of the Assembly has fully expired. France is divided into separate electoral constituencies, and the candidates standing for election in a given constituency compete for one seat in the Assembly. Since 1986 there have been 577 constituencies and until today their precise geographical boundaries have changed only once, in 2009. This means that for the legislative elections studied in this paper, the ones of 1993 and 1997,

\footnotetext{
${ }^{3}$ Da Silveira and De Mello (2011) criticize the Levitt approach arguing that the source of variation in the difference in spending is not clear in his case, and that the exogeneity assumption may therefore be questionable.

${ }^{4}$ This section partly draws on information obtained from the French National Assembly's web site: http://www.assemblee-nationale.fr/english.
} 
the constituencies are geographically fully identical. Out of the 577 constituencies 555 are situated in metropolitan France and 22 in France's overseas areas.

The electoral rule is a two-round majority voting rule. To get elected in the first round, a candidate should receive more than $50 \%$ of the regular votes (i.e., all votes except those invalidated by the electoral authorities or blank votes), and more than $25 \%$ of the registered voters in the constituency. If no candidate is elected in this manner, there is a second round. Each candidate with more than $12.5 \%$ of the registered voters in the first round is allowed to run in the second round. The winner of the second round is the candidate who gets the highest number of regular votes.

The legislative election of 1993 was held on March 21st (first round) and March 28th (second round), near the end of François Mitterrand's presidency (he served as president between 1981 and 1995). The election of 1997 was held on May 25th and June 1st, following the dissolution of the National Assembly decided by President Jacques Chirac (this early election was held one year before the planned end of the Assembly's mandate). Both elections have been dominated by the same five parties. Listed from the far-left to the far-right, the names of these parties are: Parti Communiste (henceforth abbreviated as PC), Parti Socialiste (PS), Union pour la Démocratie Française (UDF), Rassemblement pour la République (RPR), and Front National (FN). Table A1 in the Appendix gives for both elections the first-round scores at the national level obtained by each of the five main parties, and the number of representatives elected in the National Assembly. The socialist party PS was severely beaten in 1993, managing to win only 57 seats out of 577 . The communist party PC obtained 23 seats in that election, and the far-right party FN 0 . The winners were the two moderate-right parties, UDF and RPR, who obtained 215 and 257 seats, respectively. In 1997 PC won 35 seats, PS 255, UDF 112, RPR 139, and FN 1. The total number of seats obtained by the five main parties was 552 in 1993, and 542 in 1997. The table shows that the number of seats won by each party and the associated first-round scores do not really match. This reflects that some parties (FN, PC, PS) fielded many candidates, while other parties (RPR, UDF) fielded relatively few of them. This has a tendency to push up the scores of the former group of parties and push down those of the latter. It also reflects the non-proportionality of the French voting system. In 1993, for instance, although FN received $12.4 \%$ of the first-round votes, none of its candidates got more than $50 \%$ in his or her constituency (i.e., no FN candidate managed to win a seat right away in the first round). The far-right party had 100 candidates running in the second round but none of them dominated the second round. Hence, despite a relatively large first-round score share, FN did not win a single seat in the 1993 election. 


\subsection{Political financing laws of the 1980's and 1990's}

Prior to 1988 there was no precise judicial regime which regulated and monitored the

financing of political life in France. A series of laws were passed in the late 1980's and the 1990's following public outrage (and a lot of coverage in the press) over several politicofinancial scandals concerning abusive campaign funding in the mid 1980's. The new laws were intended to increase the transparency of political financing and to promote equal access to elective offices. They were successively introduced through a series of legislative texts, each new text gradually tightening and restricting the financing rules. The most relevant laws for our paper are the ones adopted in 1988, 1990, 1993, and 1995.

\subsubsection{Laws of 1988 and 1990}

The laws of 11 March 1988 and 16 January 1990 laid down the first foundations of the current political financing system. They first of all introduced limits on campaign expenses. Candidates for legislative elections could no longer spend unlimited amounts but expenses were instead bounded by precise limits. These spending limits were fixed through a simple step function of the constituency populations (as measured by the latest census). Candidates in constituencies with less than 80,000 inhabitants faced a limit of FFr400,000, those in constituencies with more than 80,000 inhabitants faced a limit of FFr500,000. ${ }^{5}$ Second, the new laws determined precisely which kind of campaign expenses were allowed and which ones not. Television and radio advertising were banned at all times, and, in the three months prior to a legislative election, telephone and press advertising were also forbidden. A variety of basic campaign expenses were covered automatically by the State: it printed the ballots used at election day, sent to all registered voters the candidates' political pamphlets, and displayed posters with photos of candidates in the vicinity of voting centers. Other expenses such as setting up meetings, receptions, telephone and press advertising, traveling, payment of staff, as well as the printing and distribution of additional pamphlets, were to be covered by the candidates themselves. Third, all candidates were required to appoint a financial representative. The representatives were in charge of collecting funds and paying all campaign expenses through a unique bank account (candidates were prohibited from handling any of the financial matters themselves). They also had to register all received funds and expenses in a campaign account, and after the election these accounts had to be submitted to the newly created Commission Nationale des Comptes de Campagne et du Financement des Partis Politiques (CNCCFP). This commission was in charge of controlling and verifying the accounts, and making the campaign spending information of all candidates publicly available. Fourth, the legislators introduced a reimbursement scheme of candidates' personal campaign expenditures. Candidates whose

\footnotetext{
${ }^{5}$ On January 1st 2002 the French Franc was replaced by the Euro at the conversion rate 1 Euro=FFr6.55957.
} 
accounts were approved by CNCCFP, ${ }^{6}$ and who in addition received at least $5 \%$ of the first-round votes, were eligible for reimbursement of personal expenses up to $10 \%$ of the spending limit. Finally, the laws of 1988 and 1990 established how the State financed political parties. A first fraction of aid was allocated to parties that fielded candidates in at least seventy-five constituencies in the most recent elections to the National Assembly. A second fraction was attributed to parties whose candidates were actually elected (the attribution being proportional to the precise number of elected candidates).

\subsubsection{Laws of 1993 and 1995}

At the heart of this paper are the laws adopted on 29 January 1993 and 19 January 1995 since they mark a sharp distinction between the campaign finance rules prevailing during the 1993 election on the one hand, and the 1997 election on the other. The first change was that spending limits were no longer a step-function of constituency-population but a continuous affine function (see infra). The second and in practice more crucial change was that legal persons (i.e., firms, corporations, unions, political committees or associations with economic interest groups) were no longer allowed to finance candidates. ${ }^{7}$ To compensate for this loss of funding, the legislator introduced a third change: the maximal reimbursement of personal expenses was augmented from $10 \%$ of the spending limit of 1993 to $50 \%$ of the spending limit of 1997; the eligibility conditions for State reimbursement remained unchanged though.

To summarize, the campaign financing rules that were modified between the elections of 1993 and 1997 are the following: ${ }^{8}$

\section{- Modification 1: Spending limit.}

In 1993, candidates standing for election in a constituency with less than 80,000 inhabitants (as measured by the 1990 census) were not allowed to spend more than FFr400,000; the expenditures of those in constituencies with more than 80,000 inhabitants could not exceed FFr500,000. In 1997, each spending limit was determined

\footnotetext{
${ }^{6}$ Accounts are either approved directly, approved after revision, or rejected. Revisions are required if some expenses are thought of as not reflecting proper campaign expenses (according to a well known anecdote, one candidate listed the cost of the hairdresser as a campaign expenditure. CNCCFP rejected the claim arguing that this was a purely private expenditure unrelated to proper campaign activities). In these cases the expenses are adjusted downwards. Accounts may be rejected if total expenditures exceed the spending limit, if some financial transactions have been made by candidates themselves, if no financial representative has been appointed, or if other irregularities are observed.

${ }^{7}$ Legal persons were also no longer allowed to finance political parties, which resulted in lower budgets for political parties. Before the financing reforms of 1993 and 1995 were implemented, contributions from legal persons amounted on average to $15 \%$ of political parties' budgets; see François and Sauger (2006).

${ }^{8}$ Even if the law of 1993 was passed a few months before the legislative election of 1993 (recall that this election was held on 21 and $28 \mathrm{March}$ ), it was applied only to the election of 1997 (and the elections thereafter).
} 
as an affine function of population (again measured by the 1990 census). ${ }^{9}$ More precisely, within constituency $c$, the 1997 spending limit in French Francs was

$$
\text { Limit }_{c, 97}=\left(250,000+\text { population }_{c}\right) \times 1.05 \mathrm{FFr}
$$

where the term after the multiplication operator is a cost-of-living adjustment factor.

- Modification 2: Funding by legal persons.

In 1993, candidates were allowed to finance their campaigns through four channels: their personal wealth; donations from natural persons (i.e., individual voters); donations from parties; and donations from legal persons (firms, corporations, etc.). In 1997, legal persons were no longer allowed to finance candidates, i.e., the fourth channel was excluded.

- Modification 3: Public reimbursement of personal expenditures.

In 1993, the part of campaign expenditures financed by candidates themselves could be reimbursed by the State up to $10 \%$ of the spending limit applicable in 1993. In 1997, the maximal reimbursable amount of personal expenditures was increased to $50 \%$ of the spending limit applicable in 1997.

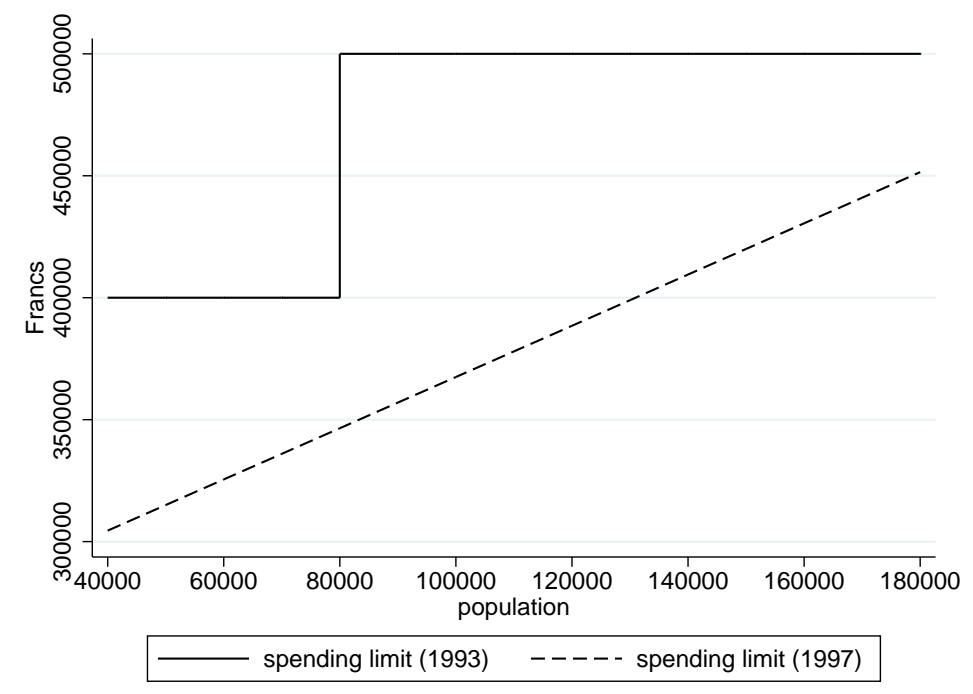

Figure 1: Spending limits in 1993 and 1997

The first modification is illustrated in Figure 1. For the relevant range of population (according to the 1990 census, the number of inhabitants across the 555 constituencies of metropolitan France varied between 35,000 and 165,000-see Table A2), the limit function of

\footnotetext{
${ }^{9}$ In both elections population is defined according to the same census, because the first census after 1990 was held only in 1999.
} 
1997 is always above the one of 1993. The difference between the two functions shows that the reduction in the spending limit varied across constituencies, between FFr50,000 and FFr150,000. ${ }^{10}$ The second modification was the most discussed and mediatized law reform. It had strong consequences as legal persons vastly contributed to the election campaigns prior to the reform. They donated FFr210 million to the approximately 5,000 candidates standing for election in 1993. These contributions constituted the primary source of financing for candidates, representing, on average, $35 \%$ of their campaign budgets (François and Sauger, 2006). As shown in Sections 3 and 4, this reform especially affected candidates with a priori close business connections (incumbents, mayors, government members, and candidates from parties of the centre-left and center-right). The third modification made the reimbursement scheme of candidates' personal contributions more generous by augmenting the maximal reimbursable amount from 10\% of the spending limit of 1993 to $50 \%$ of the spending limit of $1997 .{ }^{11}$ Since the spending limits are different across constituencies, the maximal reimbursable amounts vary across constituencies as well. The eligibility conditions for reimbursement of personal expenses remained the same in the two elections: only candidates whose accounts were in accordance with CNCCFP criteria, and who passed the $5 \%$ hurdle of first-round votes, could potentially be reimbursed.

\section{Data}

\subsection{Data sources}

Our data set is constructed by combining information from four sources. The different sources could be linked through unique identifiers for each constituency and through the candidates' names. The first source contains outcomes of legislative elections in France, collected by the French Interior Ministry, and publicly available on its web site http://www.interieur.gouv.fr/Elections/Les-resultats. For each election and constituency we observe the number of individuals who registered to vote, the number of actual voters in the first and second round, the family names and first names of all candidates, whether they are challengers or incumbents, the number of votes received by the candidates in both rounds, and their party affiliations.

The second source contains data on campaign spending and the different origins of campaign funding. These data have been collected by the CNCCFP since the election of $1993 .{ }^{12}$ Thanks to this source we observe, for each candidate and election, the total

\footnotetext{
${ }^{10}$ The discontinuity of the 1993 limit function at 80,000 can unfortunately not be exploited in our analysis of the link between campaign spending and votes since only $5.2 \%$ of the constituencies have a population below this threshold.

${ }^{11}$ The reimbursement scheme of 1997 is more generous since $50 \%$ of the 1997 limit is above $10 \%$ of the 1993 limit for all values of the population (and hence for all constituencies).

${ }^{12}$ For the elections of 1993 and 1997 the information is only available in paper format, so we had to digitize the data sets ourselves.
} 
amount of campaign spending, and the different types of campaign funding.

Our third source contains information on population in all constituencies. These data are drawn from the population census of 1990, collected by the Institut National de la Statistique et des Études Économiques (INSEE). We extracted from this census the number of inhabitants for each constituency, which, as explained in Section 2.2, determines the campaign expenditure limits in both elections.

The fourth source contains additional information on candidates that we found in election supplements published by the French newspaper Le Monde (right after each legislative election), and several issues of Le Guide du Pouvoir, a guide that contains up-to-date biographical information on French leading persons in both the private and public sector. The newspaper supplements indicate whether, at the time of the election, candidates were mayor or deputy mayor of a city or town, member of the National Senate (the upper house of Parliament), member of the current national government (we distinguish senior members, called ministres in French, from junior members, called secrétaires d'Etat), former member of the National Assembly, ${ }^{13}$ and whether they held an elective office at a local level: we observe whether a candidate seated in a Regional Council (as ordinary member or president), Departmental Council (as ordinary member or president), or Municipal Council. ${ }^{14}$ From the issues of Le Guide du Pouvoir we know whether candidates occupied a position in their party's national governing body. All the variables that we obtained from the fourth source capture whether candidates belonged to an elite group of people with strong political networks and connections. Members of this group are, as we will see in Section 4, privileged in the sense that they received much more funding from parties, individual donators, and legal persons, than other candidates.

In the remainder of the paper we restrict our analysis to the 555 constituencies located in metropolitan France. We drop the 22 overseas constituencies from the analysis because the voting patterns and campaign spending profiles there tend to differ from what is observed in metropolitan France. ${ }^{15}$ Furthermore, we focus on the first round of each legislative election. The reason for this choice is that candidates in the first round come from all parties, whereas in the second round we typically only observe candidates from the moderate-left (PS) and moderate-right (RPR, UDF). Second round data would therefore not allow us to

\footnotetext{
${ }^{13} \mathrm{~A}$ candidate is defined as a former representative if he/she was elected two or more than two elections ago. Incumbents are therefore not automatically former representatives since they are elected in the previous election, and not necessarily in an election prior to the previous one.

${ }^{14}$ In metropolitan France there are 22 regions, 96 departments, and approximately 36,000 municipalities. Each region, department or municipality is headed and managed by an elected local assembly (called councils).

${ }^{15}$ Voting patterns are different because candidates in overseas constituencies are relatively less frequently affiliated to the national parties, and the political issues that are debated are typically local ones. Spending profiles are not the same mainly because some campaign financing rules slightly differ for overseas candidates.
} 
adequately study candidates of the two extreme parties (FN, PC) and of the small parties.

\subsection{Descriptive statistics}

Table A2 in the Appendix contains summary statistics on the population per constituency as measured by the census of 1990, and the spending limits per constituency in 1993 and 1997. There are on average around 100,000 inhabitants per constituency, with a minimum of 35,000 and a maximum of 165,000. In 1993 the average spending limit per constituency is around FFr495,000 and in 1997 around FFr370,000, a drop of 125,000 French Francs resulting from the first law modification discussed above.

Table 1 gives, for each election and type of candidate, the number of first-round competitors. Overall there are 5,138 candidates in 1993, and 6,197 in $1997 .{ }^{16}$ Most political experts attribute this increase to the laws on State financing of parties passed in 1988 and 1990 (see Section 2.2), which made it financially attractive for parties to field more candidates. After the introduction of the new laws, the number of candidates not only increased between the elections of 1988 and 1993, but also between 1993 and 1997. Table 1 shows that the small parties (labeled "Other party") are primarily responsible for this phenomenon: while the total number of candidates fielded by the five main parties together (FN, PC, PS, RPR, and UDF) is fairly stable across the two elections (around $2,150)$, the small ones augmented the size of their pool of candidates from about 2,900 in 1993 to 4,100 in 1997. The number of incumbents has slightly increased (from 462 in 1993 to 479 in 1997), while the number of other types of a priori strong and influential candidates has moderately decreased.

Table 2 shows summary statistics on the campaign spending per candidate and the sources of campaign contributions, separately for challengers, incumbents, and the two elections. All monetary amounts of 1997 are converted into French Francs of 1993 using INSEE's consumption price index. In 1993, a challenger spent on average around FFr80,000 and an incumbent FFr313,000. In 1997, both types of candidates reduced their campaign expenses to respectively FFr57,000 and FFr231,000. ${ }^{17}$ In 1993 legal persons donated on average approximately FFr21,000 to a challenger, and more than six times as much to an incumbent $(\mathrm{FFr} 136,000) .{ }^{18}$ The second modification of the campaign financing law thus

\footnotetext{
${ }^{16}$ We had to drop 11 candidates from the 1997 election because of missing observations on campaign spending (initially there were 6,208 candidates in metropolitan France in 1997).

${ }^{17}$ By comparison, in the U.S. House elections between 1972 and 1990, incumbents spent $\$ 293,000$ and challengers $\$ 136,000$ (see Levitt (1994)); in the Canadian Federal elections of 1997 and 2000, incumbents spent $\$ 52,520$ and challengers $\$ 17,516$ (see Milligan and Rekkas (2008)). It appears therefore that campaign expenditures in France are lower than in the U.S., but comparable to Canada.

${ }^{18}$ The reported means are based on all challengers and incumbents, including those who did not receive money form legal persons. Among the 1,232 challengers who did get aid from legal persons (26\% of the 4,676 challengers present in 1993), the average amount received is FFr81,556; similarly, among the 400 incumbents who got aid (87\% of 462), the average amount is FFr157,629.
} 
Table 1: Number of first-round candidates

\begin{tabular}{|c|c|c|}
\hline & 1993 & 1997 \\
\hline Challenger & $4,676(91 \%)$ & $5,718(92 \%)$ \\
\hline Incumbent & $462(9 \%)$ & $479(8 \%)$ \\
\hline \multicolumn{3}{|l|}{ Local elective office: } \\
\hline Member of Municipal Council & $631(12 \%)$ & $581(9 \%)$ \\
\hline Member of Departmental Council (DC) & $574(11 \%)$ & $473(8 \%)$ \\
\hline President of DC & $26(0.5 \%)$ & $25(0.4 \%)$ \\
\hline Member of Regional Council (RC) & $614(12 \%)$ & $431(7 \%)$ \\
\hline President of RC & $12(0.2 \%)$ & $10(0.2 \%)$ \\
\hline Mayor & $725(14 \%)$ & $709(11 \%)$ \\
\hline Deputy Mayor & $261(5 \%)$ & $213(3 \%)$ \\
\hline Former representative of Assembly & $130(3 \%)$ & $141(2 \%)$ \\
\hline Member of Senate & $5(0.1 \%)$ & $8(0.1 \%)$ \\
\hline Senior member of government & $21(0.4 \%)$ & $21(0.3 \%)$ \\
\hline Junior member of government & $11(0.2 \%)$ & $3(0.05 \%)$ \\
\hline Political party leadership & $432(8 \%)$ & $334(5 \%)$ \\
\hline \multicolumn{3}{|l|}{ Party affiliation: } \\
\hline FN & $554(11 \%)$ & $553(9 \%)$ \\
\hline $\mathrm{PC}$ & $555(11 \%)$ & $531(9 \%)$ \\
\hline PS & $522(10 \%)$ & $479(8 \%)$ \\
\hline RPR & $303(6 \%)$ & $289(5 \%)$ \\
\hline UDF & $293(6 \%)$ & $265(4 \%)$ \\
\hline Other party & $2,911(57 \%)$ & $4,080(66 \%)$ \\
\hline Total & 5,138 & 6,197 \\
\hline
\end{tabular}


Table 2: Campaign spending and sources of campaign contributions

\begin{tabular}{|c|c|c|}
\hline & 1993 & 1997 \\
\hline \multicolumn{3}{|c|}{ Campaign spending: } \\
\hline Challenger & $82,832(110,638)$ & $60,675(85,966)$ \\
\hline Incumbent & $313,301(109,041)$ & $246,512(68,381)$ \\
\hline \multicolumn{3}{|c|}{ Donations from legal persons: } \\
\hline Challenger & $21,488(62,128)$ & - \\
\hline Incumbent & $136,476(121,539)$ & - \\
\hline \multicolumn{3}{|c|}{ Personal contributions from candidates: } \\
\hline Challenger & $25,376(33,636)$ & $46,643(68,964)$ \\
\hline Incumbent & $31,471(39,491)$ & $111,378(61,174)$ \\
\hline \multicolumn{3}{|c|}{ Contributions from parties: } \\
\hline Challenger & $23,688(48,233)$ & $4,460(17,217)$ \\
\hline Incumbent & $97,715(94,987)$ & $76,041(53,831)$ \\
\hline \multicolumn{3}{|c|}{ Donations from voters: } \\
\hline Challenger & $9,282(21,073)$ & $5,263(18,669)$ \\
\hline Incumbent & $36,907(42,518)$ & $36,681(40,836)$ \\
\hline \multicolumn{3}{|l|}{ Other sources: } \\
\hline Challenger & $2,562(9,197)$ & $449(2,581)$ \\
\hline Incumbent & $10,156(24,318)$ & $6,703(12,741)$ \\
\hline
\end{tabular}

clearly affected incumbents more than challengers. In 1993, the personal contributions of challengers and incumbents are comparable, but during the 1997 campaign the former spent much less than the latter. Incumbents increased their personal contributions substantially following the introduction of the more generous reimbursement scheme since they could safely expect their first-round scores to exceed 5\%. On the contrary, many challengers (especially those from the small parties) could not expect with much confidence to pass this threshold, and it was consequently too risky for them to augment personal expenses. Contributions from parties constitute an important source of funding in the election of 1993. In 1997 parties were less generous primarily because of parties' tighter budgets (see footnote 7 ). The average amount received from voters remains stable over time for incumbents, but there is a drop for challengers in 1997 (the new challengers observed in 1997 are primarily from the small parties and these candidates received few donations from voters). Finally, we see that the 'other sources' clearly constitute the least important form of funding in both election years.

Table 3 reports statistics on a variety of first-round election outcomes. The average number of candidates per constituency has increased from around 9 in 1993 to 11 in 1997. The number of registered voters, the number of regular voters, and turnout, have on average little changed across the two elections. The statistics on the Herfindahl-Hirschman 
Table 3: First-round election outcomes

\begin{tabular}{lcc}
\hline & 1993 & 1997 \\
\hline Number of candidates per constituency & $9.3(2.2)$ & $11.1(3.5)$ \\
Number of registered voters per constituency & $68,243(11,148)$ & $68,483(12,069)$ \\
Number of voters per constituency & $47,285(8,790)$ & $46,940(9,486)$ \\
Turnout per constituency & $0.691(0.039)$ & $0.683(0.043)$ \\
HHI of vote share concentration & $1,063(334)$ & $971(223)$ \\
Vote share gap (first candidate minus second) & $0.114(0.088)$ & $0.056(0.048)$ \\
Vote share challenger & $0.055(0.061)$ & $0.045(0.058)$ \\
Vote share incumbent & $0.227(0.089)$ & $0.213(0.053)$ \\
\hline $\begin{array}{l}\text { Notes: Main entries are means and figures in parentheses are standard deviations. Statistics on vote shares of } \\
\text { challengers and incumbents are based on the number of observations listed in Table 1. Statistics on all other }\end{array}$ \\
$\begin{array}{l}\text { variables are calculated over the 555 constituencies. The Herfindahl-Hirschan index (HHI) is the sum of the squares } \\
\text { of votes shares of all candidates in a constituency, multiplied by 10,000. Source: French Interior Ministry. }\end{array}$
\end{tabular}

index, and the gap in vote shares ${ }^{19}$ between the first-round winner and the runner-up suggest that competition among candidates has somewhat increased. The average vote share of challengers has slightly decreased from $5.5 \%$ in 1993 to $4.5 \%$ in 1997 , a mechanic consequence of the larger cohort size observed in 1997. Average vote shares for incumbents have also somewhat decreased, from $23 \%$ in 1993 to $21 \%$ in 1997. Overall Table 3 suggests that the aggregate first-round election outcomes have changed little between the two elections.

\section{Impact of the reforms on campaign spending}

This section analyzes the determinants of campaign spending and we show in particular how the financing reforms of the mid-1990s are to a large extent responsible for the observed changes over time in campaign spending. First we introduce some notation. The scalar variable $s_{j c t}$ represents the amount of money spent by candidate $j$ during the election campaign of year $t$ in district $c$. The vector $X_{j c t}$ contains the candidate characteristics (the variables listed in Table 1) which may affect spending in this district and election. Furthermore, $s_{j c t}^{\text {firms }}$ is the total funding received by $j$ from legal persons, ${ }^{20} s_{j c t}^{\text {personal }}$ the personal contribution of the candidate, $s_{j c t}^{\text {party }}$ the donation received by the candidate's party, $s_{j c t}^{\text {voters }}$ the donations from voters, and $s_{j c t}^{\text {other }}$ the 'other sources' (see Table 2). Since campaign spending is the sum of these different sources of contributions, we have $s_{j c t}=$ $s_{j c t}^{\text {firms }}+s_{j c t}^{\text {personal }}+s_{j c t}^{\text {party }}+s_{j c t}^{\text {voters }}+s_{j c t}^{\text {other }}$. Note that $s_{j c 97}^{\text {firms }}=0$ for all $j$ and $c$, since legal persons were forbidden to contribute in the 1997 election. Finally, $\Delta$ represents the first-difference operator, so $\Delta s_{j c}=s_{j c 97}-s_{j c 93}$, etc.

\footnotetext{
${ }^{19}$ As in Section 5, a candidate's vote share is defined here as the number of votes received by the candidate divided by the number of individuals who registered to vote.

${ }^{20}$ Most legal persons in the data are actually firms (see François and Sauger (2006)), and therefore this source of campaign funding is labelled 'firms'.
} 
Column 1 in Table 4 reports the OLS estimates from the regression of $s_{j c 93}$ on $X_{j c 93}$ together with standard errors clustered at the district level. Estimation is based here on all participants of the 1993 election (5,138 observations). Practically all variables are significant at conventional significance levels. Incumbents, (deputy) mayors, government members, former members of the Assembly, current members of the Senate, candidates who held a local elective office (except presidents of the regional and departmental councils), and candidates who occupied a position in their party's governing body, spent more money than politicians without such influential positions. All party dummies are positive and significant, implying that candidates from the five main parties spent more than those from the other parties. The highest spenders were candidates from the moderate-right (RPR, UDF), followed by those of the moderate-left (PS), and finally the candidates of the far-left $(\mathrm{PC})$ and far-right $(\mathrm{FN})$.

Column 2 contains OLS results from the regression of $s_{j c 97}$ on $X_{j c 97}$ based on all candidates of the 1997 election (6,197 observations). Most variables are again significant and positive. The coefficients associated with the candidate characteristics are now, however, often smaller in magnitude, suggesting that in 1997 elite candidates still outspent other types of candidates, but by less compared to 1993. Interestingly, the estimates of the party dummies are very different from those reported for 1993. For instance, the FN coefficient has increased from 8,303 to 142,220, and the RPR coefficient has decreased from 226,072 to 141,234 . While the estimates for 1993 are very dissimilar, those for 1997 are relatively comparable. On average, the spread in spending patterns of candidates across the five main parties was therefore much larger in the first election than in the second one.

Column 3 reports the results of the OLS regression of $\Delta s_{j c}$ on $X_{j c 93}$. This regression is based on the 1,644 candidates who competed in both elections and in the same constituency, and allows us to analyze which politicians changed their expenditures between the two elections. The incumbents in 1993 fall in the latter category: compared to challengers they decreased their campaign expenses by slightly more than FFr15,000. Mayors and deputy mayors, senior government members, and candidates with a position in their party's governing body also reduced their spending levels in a statistically significant manner. Candidates holding a local elective office increased their expenses but the corresponding coefficients are not significant. The most remarkable finding concerns the party dummies: all five parameters are highly significant. Relatively to the other parties, FN and PC candidates drastically increased their expenses (on average by FFr127,000 and FFr63,000, respectively), while those from the moderate parties reduced campaign expenditures (varying from -FFr24,000 for PS to -FFr64,000 for RPR). Put differently, candidates from the two extreme parties have substantially augmented their expenditures compared to mainstream candidates. Candidates from FN, for instance, have on average increased their expenditures by FFr190,000 compared to candidates from RPR.

The main takeaway from Table 4 is that the change in campaign spending over time 
Table 4: Determinants of campaign spending

\begin{tabular}{|c|c|c|c|}
\hline & $\begin{array}{c}(1) \\
1993\end{array}$ & $\begin{array}{c}(2) \\
1997\end{array}$ & $\begin{array}{c}(3) \\
\text { Difference }\end{array}$ \\
\hline Incumbent & $\begin{array}{c}50,460^{* * *} \\
(6,958)\end{array}$ & $\begin{array}{c}42,329^{* * *} \\
(5,798)\end{array}$ & $\begin{array}{r}-15,394^{*} \\
(8,038)\end{array}$ \\
\hline \multicolumn{4}{|l|}{ Local elective office: } \\
\hline Member of Municipal Council & $\begin{array}{c}19,415^{* * *} \\
(3,775)\end{array}$ & $\begin{array}{c}21,058^{* * *} \\
(2,770)\end{array}$ & $\begin{array}{l}1,345 \\
(5617)\end{array}$ \\
\hline Member of Departmental Council (DC) & $\begin{array}{c}25,824^{* * *} \\
(6,250)\end{array}$ & $\begin{array}{c}26,401^{* * *} \\
(4,053)\end{array}$ & $\begin{array}{c}908 \\
(7,282)\end{array}$ \\
\hline President of DC & $\begin{array}{l}-30,, 483 \\
(31,626)\end{array}$ & $\begin{array}{l}-10,863 \\
(16,033)\end{array}$ & $\begin{array}{c}11,088 \\
(27,070)\end{array}$ \\
\hline Member of Regional Council (RC) & $\begin{array}{c}24,222^{* * *} \\
(4,474)\end{array}$ & $\begin{array}{c}19,381^{* * *} \\
(3,241)\end{array}$ & $\begin{array}{c}1,001 \\
(5,430)\end{array}$ \\
\hline President of $\mathrm{RC}$ & $\begin{array}{c}20,847 \\
(30,357)\end{array}$ & $\begin{array}{c}57,696^{* * *} \\
(20,037)\end{array}$ & $\begin{array}{c}42,723 \\
(26,641)\end{array}$ \\
\hline Mayor & $\begin{array}{c}72,519^{* * *} \\
(6,241)\end{array}$ & $\begin{array}{c}41,458^{* * *} \\
(3,883)\end{array}$ & $\begin{array}{c}-29,905^{* * *} \\
(7,269)\end{array}$ \\
\hline Deputy Mayor & $\begin{array}{c}55,753^{* * *} \\
(6,462)\end{array}$ & $\begin{array}{c}34,967^{* * *} \\
(4,647)\end{array}$ & $\begin{array}{c}-20,015^{* *} \\
(8,798)\end{array}$ \\
\hline Former representative of Assembly & $\begin{array}{c}31,538^{* * *} \\
(10,230)\end{array}$ & $\begin{array}{c}18,035^{* *} \\
(7,233)\end{array}$ & $\begin{array}{l}-17,026 \\
(11,072)\end{array}$ \\
\hline Member of Senate & $\begin{array}{l}61,937^{*} \\
(32,609)\end{array}$ & $\begin{array}{c}39,773^{\text {** }} \\
(16,681)\end{array}$ & $\begin{array}{c}9,787 \\
(13,260)\end{array}$ \\
\hline Senior member of government & $\begin{array}{c}131,573^{* * *} \\
(28,977)\end{array}$ & $\begin{array}{l}-28,885 \\
(18,799)\end{array}$ & $\begin{array}{c}-82,454^{* * *} \\
(29,026)\end{array}$ \\
\hline Junior member of government & $\begin{array}{l}53,936^{* *} \\
(27,235)\end{array}$ & $\begin{array}{c}19,698 \\
(46,469)\end{array}$ & $\begin{array}{l}-23,335 \\
(27,479)\end{array}$ \\
\hline Political party leadership & $\begin{array}{c}34,165^{* * *} \\
(5,939)\end{array}$ & $\begin{array}{c}28,419^{* * *} \\
(4,461)\end{array}$ & $\begin{array}{c}-29,788^{* * *} \\
(6,773)\end{array}$ \\
\hline \multicolumn{4}{|l|}{ Party affiliation: } \\
\hline FN & $\begin{array}{c}8,303^{* * *} \\
(2,011)\end{array}$ & $\begin{array}{c}142,220^{\text {*** }} \\
(1,499)\end{array}$ & $\begin{array}{c}127,045^{* * *} \\
(3,434)\end{array}$ \\
\hline $\mathrm{PC}$ & $\begin{array}{c}12,782^{* * *} \\
(3,269)\end{array}$ & $\begin{array}{c}89,601^{* * *} \\
(3,107)\end{array}$ & $\begin{array}{c}62,629^{* * *} \\
(5,283)\end{array}$ \\
\hline PS & $\begin{array}{c}104,325^{* * *} \\
(5,682)\end{array}$ & $\begin{array}{c}119,813^{* * *} \\
(3,869)\end{array}$ & $\begin{array}{c}-23,769^{* *} \\
(9,228)\end{array}$ \\
\hline RPR & $\begin{array}{c}226,072^{* * *} \\
(7,987)\end{array}$ & $\begin{array}{c}141,234^{* * *} \\
(6,399)\end{array}$ & $\begin{array}{c}-63,789^{* * *} \\
(9,357)\end{array}$ \\
\hline UDF & $\begin{array}{c}191,402^{* * *} \\
(8,669)\end{array}$ & $\begin{array}{c}137,163^{* * *} \\
(6,052)\end{array}$ & $\begin{array}{c}-37,322^{* * *} \\
(9,660)\end{array}$ \\
\hline Constant & $\begin{array}{c}36,389^{* * *} \\
(981)\end{array}$ & $\begin{array}{c}11,681^{* * *} \\
(479)\end{array}$ & $\begin{array}{c}-20,784^{* * *} \\
(1,907)\end{array}$ \\
\hline Observations & 5,138 & 6,196 & 1,644 \\
\hline$R^{2}$ & 0.671 & 0.770 & 0.495 \\
\hline
\end{tabular}


is essentially determined by party affiliation. Indeed, the estimated effects of the party indicators reported in column 3 tend to be larger (in absolute values) than the effects of the other variables (which, in addition, are often not statistically significant). Also, the $R^{2}$ hardly changes when the other variables are dropped from the model (its value is 0.453 when they are dropped, and 0.495 when they are included), implying that party affiliation is key in explaining the variation in $\Delta s$. In the remainder of this section we will therefore analyze the difference in spending separately for each party, and document that the impact of the reforms varies with the candidate's political color.

Let us first study $\Delta s$ for the extreme right party FN. As Table A4 indicates, only $10 \%$ of the $249 \mathrm{FN}$ candidates present in both elections were financially supported by legal persons. On average, they received only FFr1,700 from firms. The regression of $s_{j c 93}^{\text {firms }}$ on $X_{j c 93}$ (column 1 of Table A3) shows that politicians from the far-right actually received substantially less than other candidates. ${ }^{21}$ At the same time, in both elections they received little support from voters and their party, and the difference in these two sources of campaign money is relatively small: for the average $\mathrm{FN}$ candidate we have $\Delta s_{j c}^{\text {voters }}=$ $-\mathrm{FFr} 2,756$ and $\Delta s_{j c}^{\text {party }}=-\mathrm{FFr} 741$. Column 2 of Table A3 shows that they have increased personal expenditures by more than FFr100,000 relatively to candidates of the other parties - the reference group in the regression of $\Delta s_{j c}^{\text {personal }}$ on $X_{j c 93}$. Looking at the upper-left plot in Figure 2, we see that in both elections the personal contributions of the $249 \mathrm{FN}$ candidates are close to the maximal reimbursable amounts (10\% of the 1993 spending limit, and $50 \%$ of the 1997 limit). Putting all these findings together suggests $\Delta s_{j c} \simeq \Delta s_{j c}^{\text {personal }} \simeq$ Limit $_{c, 97} / 2-$ Limit $_{c, 93} / 10{ }^{22}$ Since for both elections the spending limit in each district is a deterministic function of its population (see Section 2.2), $\Delta s_{j c}^{\text {personal }}$ is itself a function of population in district $c$. Under the plausible assumption that population in $c$ does not directly influence the difference in the vote share across the two elections in this district, $\Delta s_{j c}$ is exogenously determined.

Next we focus on PC candidates. The picture that emerges for the extreme-left politicians is similar as above, although admittedly a bit less clear-cut. As indicated in Table A4, 25\% of the PC candidates competing in both 1993 and 1997 received money from firms. The average amount received per candidate is again relatively small (slightly less than FF24,000). On average the differences $\Delta s_{j c}^{\text {voters }}$ and $\Delta s_{j c}^{\text {party }}$ are still small as well (FFr9,015 and -FFr12,524, respectively). Column 2 of Table A3 shows that PC candidates have considerably increased their personal campaign investments across the two elections contributions (by about FFr65,000). Unlike the extreme-right politicians, however, personal contributions are not always close to the maximal reimbursable amounts (see the

\footnotetext{
${ }^{21}$ To account for the fact that 3,506 out of 5,138 candidates in 1993 were not financed by legal persons, we also estimated a Tobit model, but the results are not fundamentally different.

${ }^{22}$ Regressing $\Delta s_{j c}$ on a constant and $\Delta s_{j c}^{\text {personal }}$ by OLS, the estimated effect of personal spending is 0.92 (standard error is 0.04), and we cannot reject the null hypothesis that the slope coefficient equals one.
} 
top-middle plot in Figure 2). Although the large majority of PC candidates have increased their personal expenditures between 1993 and 1997, a fraction of them invested less than the maximal reimbursable amount in 1997. It is useful here to distinguish the PC candidates who received donations from legal persons from those who did not. For candidates in the latter group, $\Delta s_{j c}$ is on average close to $\Delta s_{j c}^{\text {personal }}$. Although on average $\Delta s_{j c}^{\text {personal }}$ is smaller than Limit $_{c, 97} / 2-$ Limit $_{c, 93} / 10$, it increases with population, ${ }^{23}$ implying that for these candidates $\Delta s_{j c}$ is at least partly determined by an exogenous variable. For candidates in the former group, we regressed $\Delta s_{j c}$ on a constant and $s_{j c 93}^{\text {firms }}$. The OLS estimate of the slope coefficient is -0.69 (standard error is 0.062 ). This is evidence in favor of the hypothesis that the political financing reforms affected $\Delta s$. Indeed, in the absence of any global effect of the reforms, these candidates would have compensated the loss of no longer being financed by legal persons by proportionally augmenting the other campaign contributions, in which case $s_{j c 93}^{\text {firms }}$ would not have been significant.

The candidates of the centre-left (PS) and centre-right (UDF, RPR) can be analyzed together since their spending profiles $\Delta s$ are comparable. For 224 candidates of these three parties ( 56 from PS, 96 from UDF, and 72 from RPR) the campaign expenditures in 1993 are above the 1997 spending limit (observations situated between the two spending limit functions in Figure 1). The total expenditures of these candidates have decreased across the two elections (on average by FFr182,517), which follows directly from the first law modification described in Section 2.2. As shown in Table A4, legal persons were generous to the candidates of the moderate parties: the fraction of recipients (resp. the average amount received from firms per candidate) ranges from $81 \%$ for PS candidates (FFr121,000 on average) to 93\% for RPR candidates (FFr141,000 on average). Regressing $\Delta s_{j c}$ on a constant and $s_{j c 93}^{\text {firms }}$, the estimate of the slope coefficient is -0.52 (standard error equals 0.03). Following the same kind as reasoning as above, this suggests that the reforms changed the spending patterns of the mainstream candidates.

Finally let us look at the candidates of the other parties, whose campaign expenditures changed the least across the two elections (as Table 4 indicates, they reduced spending by almost FFr21,000). Many of them abstained from investing personal money in the two election campaigns (see Figure 2 and Table A3), most likely because for a lot of these candidates the $5 \%$ threshold was out of reach. They also received little financial support from legal persons (18\% are recipients, and the average amount received is around FFr10,000), and $\Delta s_{j c}^{\text {voters }}$ is only -FFr1880. The main explanation for the decrease in their campaign expenses is the lower contributions of parties (on average parties reduced their contributions by FFr12,541), a direct consequence of the fact that legal persons were prohibited from financing political parties in 1997.

\footnotetext{
${ }^{23}$ In a regression of $\Delta s_{j c}^{\text {personal }}$ on a constant and population ${ }_{c}$, the estimate of the slope coefficient is 0.33 (standard error equal to 0.12 ).
} 


\section{$5 \quad$ Model}

This section presents the vote equations, i.e., the equations relating shares of first-round votes obtained by candidates to their amounts of campaign spending and a set of control variables. We adopt a model à la Berry (1994), a typical framework from the IO literature and originally designed to estimate demand models of differentiated goods. The analogy between a differentiated goods market and an electoral setting is strong. Consumers in the goods market can be seen as voters in an election. While consumers choose between goods that differ in product-features and publicity spending (amount of money spent by the producer to advertise the good), voters can vote for candidates who differ in their characteristics and amounts of campaign spending. The equivalent of the outside option in the goods market (i.e., the possibility for consumers not to purchase any of the available products) is the option for individuals to abstain from voting. ${ }^{24}$ Given this strong analogy, it is thus natural to apply the framework to analyze elections.

Let $M_{c t}$ denote the number of individuals who registered to vote for the election held in year $t$ and district $c$. This variable corresponds to the market size in the Berry framework. Unlike many product markets, the advantage of an election setting is that $M_{c t}$ is precisely measured and defined. Each registered individual $i$ has the choice between $N_{c t}$ candidates, indexed by $j$. The utility obtained by $i$ when voting for candidate $j$ is assumed to be:

$$
U_{i j c t}=\delta_{j c t}+\epsilon_{i j c t}=P_{j c}+\beta s_{j c t}+\gamma X_{j c t}+\alpha_{c t}+\xi_{j c t}+\epsilon_{i j c t}
$$

where $\delta_{j c t}$ is the "mean utility level" of candidate $j$, and $\epsilon_{i j c t}$ is an idiosyncratic error term affecting the utility of choice $j$. The mean utility will be parameterized as the sum of four components:

- $P_{j c}$ is the unobserved attractiveness/popularity of candidate $j$ in district $c$, or the unobserved taste of voters for this candidate. Note that this term is not indexed by $t$. It is thus assumed to capture the combined impact of unobserved popularity determinants that do not change over time (gender, education level, wealth, personality traits of the candidate, etc.).

- $\beta s_{j c t}+\gamma X_{j c t}$ is an index of covariates that may enhance or depreciate this popularity. Here $s_{j c t}$ represents, as above, the campaign spending by candidate $j$, and $X_{j c t}$ a vector of other variables that may affect the utility level (incumbency status, party affiliation, local electoral mandates). They will play the role of control variables in our different specifications. In our empirical application $s_{j c t}$ will be interacted with

\footnotetext{
${ }^{24}$ Registered individuals also have the "blank vote" option, i.e., they can cast a vote without choosing any candidate. In the data such voters are not distinguished from individuals who abstained from voting altogether. The number of blank votes is very small in France, so not observing them as a separate category is not restrictive.
} 
various elements in $X_{j c t}$, allowing the impact of campaign spending to differ with the controls. For notational simplicity this is not formally expressed in equation (2).

- $\alpha_{c t}$ is a district and election specific fixed effect which accounts for any conjunctural factor affecting district $c$ and election $t$ (rate of unemployment, level of local taxes, number of schools, libraries, other public establishments, etc.).

- $\xi_{j c t}$ is an unobserved local demand shock affecting candidate $j$ in district $c$ at time $t$. Unlike the component $P_{j c}$, the term $\xi_{j c t}$ accounts for the impact of unobserved popularity determinants that do change over time (it may for example indicate whether the candidate was involved in a personal or political scandal prior to the election).

When $i$ abstains from voting the utility is

$$
U_{i 0 c t}=\delta_{0 c t}+\epsilon_{i 0 c t}=0+\epsilon_{i 0 c t},
$$

where $\epsilon_{i 0 c t}$ is the idiosyncratic error term affecting the utility of voter $i$ when opting for the outside option, and $\delta_{0 c t}$ has been normalized to zero for identification purposes.

Under the assumption that all idiosyncratic error terms are i.i.d. across all voters and choices with the extreme value distribution, we have

$$
v_{j c t}=\frac{e^{P_{j c}+\beta s_{j c t}+\gamma X_{j c t}+\alpha_{c t}+\xi_{j c t}}}{1+\sum_{k=1}^{N_{c t}} e^{P_{k c}+\beta s_{k c t}+\gamma X_{k c t}+\alpha_{c t}+\xi_{k c t}}}, \text { for } j=1, \ldots, N_{c t},
$$

and

$$
v_{0 c t}=\frac{1}{1+\sum_{k=1}^{N_{c t}} e^{P_{k c}+\beta s_{k c t}+\gamma X_{k c t}+\alpha_{c t}+\xi_{k c t}}} .
$$

Here $v_{j c t}$ is the vote share of candidate $j$, i.e., the number of votes received by $j$ divided by the market size $M_{c t}$, and $v_{0 c t}$ the share of registered individuals not voting for any candidate, i.e., $v_{0 c t}=1-\sum_{j=1}^{N_{c t}} v_{j c t}$. The share $v_{0 c t}$ is thus the abstention rate in district $c$ at election $t$, i.e., one minus the turnout in this district.

An inconvenient feature of equation (4) is that $v_{j c t}$ depends not only on the vote determinants of candidate $j$, but also on the determinants of all opponents. Taking the logarithm of the ratio of vote share over abstention rate allows, however, to eliminate all opponents' determinants:

$$
\log v_{j c t}-\log v_{0 c t}=\beta s_{j c t}+\gamma X_{j c t}+\alpha_{c t}+P_{j c}+\xi_{j c t}
$$

The parameters $\beta, \gamma$, and $\alpha_{c t}$ can be estimated by OLS using data on candidates competing in election $t$. The error term in the regression equation (6), $P_{j c}+\xi_{j c t}$, is potentially correlated with the spending amount $s_{j c t}$. Spending can be linked to $P_{j c}$ for instance because charismatic candidates can collect more money from their party, or because wealthy ones can more easily invest personal money into their campaigns. There may be a correlation 
between $s_{j c t}$ and $\xi_{j c t}$ for instance because candidates implicated in scandals can have more difficulties in raising campaign money. If indeed spending is correlated with the error term, the cross-section OLS estimates are biased.

A solution to this problem consists in focussing on candidates who compete in the same electoral district in both elections. For such candidates a first-difference (FD) transformation applied to model (6) allows to eliminate the component $P_{j c}$ :

$$
\Delta \log v_{j c}-\Delta \log v_{0 c}=\beta \Delta s_{j c}+\gamma \Delta X_{j c}+\Delta \alpha_{c}+\Delta \xi_{j c}
$$

The FD estimator of the parameters $\beta, \gamma$, and $\Delta \alpha_{c}$, is the OLS estimator applied to model (7) using data on the set of candidates observed in the same constituency in both elections. Since $P_{j c}$ has disappeared from this equation, the FD estimator is unbiased even when there is a correlation between $P_{j c}$ and $s_{j c t}$. The only requirement for unbiasedness is that the difference in error terms $\Delta \xi_{j c}$ satisfies the zero conditional mean assumption $E\left(\Delta \xi_{j c} \mid \Delta X_{j c}, \Delta s_{j c}\right)=0$. Mean independence of $\Delta \xi_{j c}$ with respect to $\Delta X_{j c}$ is not a strong assumption: a change over time in for instance the incumbency status of a candidate is unlikely related to a change in the local demand shock. Mean independence with respect to $\Delta s_{j c}$ also appears unrestrictive since changes in campaign spending are determined by the campaign financing reforms (see Section 4).

\section{Campaign spending and election outcomes}

\subsection{Main results}

Table 5 reports the results of the estimation of model (6), separately for the two elections. Reported are the OLS estimates of $\beta$ and $\gamma$ (not the fixed effects $\alpha_{c t}$ ) together with standard errors clustered at the district level. We allow the effect of spending to differ for challengers and incumbents. Column 1 reports the results for the 1993 election based on the candidates present in both elections (one candidate has a vote share equal to 0 in 1993 , and is removed from the sample). The variable interacting campaign spending with the dummy for challengers is positive and strongly significant (at the $1 \%$ level). Campaign spending interacted with an indicator for incumbents is, however, not significant. The amount of money spent during the 1993 campaign thus only matters for challengers. The estimate of the coefficient on challenger spending implies that a challenger with a vote share of $30 \%$ who increases spending by FFr100,000 can expect his share to increase by 7.7 percentage points. ${ }^{25}$

\footnotetext{
${ }^{25}$ The marginal effect of campaign spending is given by $\frac{\partial v}{\partial s}=\beta v(1-v)$, where $v$ is the vote share and $\beta$ the coefficient associated with spending. For a challenger with $v=0.3$ and $\Delta s=1$ (spending is measured in hundred thousands of French Francs), and using that the estimate of $\beta$ for challengers is 0.365 , we get $\Delta v=0.365 \times 0.3 \times 0.7=0.077$, so the share of this challenger increases from $30 \%$ to $37.7 \%$.
} 
Column 1 also shows that there is a significant increase in the vote share for incumbents and candidates occupying a seat in a municipal, departmental, or regional council. There is a strong premium for mayors and for deputy mayors as well. Surprisingly, we find no effect for presidents of departmental or regional councils, but this may be due to the relatively small number of such candidates in the estimation sample (at most 22 and 96, by definition). Vote shares are also not significantly different from zero for former representatives of the Assembly, members of the Senate, government members, and candidates occupying a position in their party's national governing body. The five party indicators are significant though, confirming that candidates from the five main parties indeed receive more votes than those from the other parties. Column 2 gives the results for the 1997 election (one candidate has a vote share equal to 0 in 1997, and is removed from the sample). As for 1993, spending is significant for challengers but not for incumbents. The estimated effect of challenger spending is now 0.710 , almost twice the value obtained for 1993 . This estimate implies that by adding FFr100,000 to campaign spending, a challenger augments his vote share from 30 to $44.9 \%$. The magnitudes of the coefficients associated with our control variables sometimes differ from those in column 1 as well, but the implications of the point estimates are roughly the same for both elections.

Table 6 contains the estimation results of model (7) based on the sample of candidates present in both elections (the two candidates who have vote shares equal to 0 are dropped from the sample). We report FD estimates of $\beta$ and $\gamma$ (not the difference in fixed effects $\left.\Delta \alpha_{c}\right)$ together with standard errors clustered at the district level. The campaign spending of challengers is still significant at the $1 \%$ level, but the effect is now smaller relatively to the cross-section estimates reported in Table 5: an extra FFr100,000 in spending now only adds 2.8 percentage points to the vote share. This suggests that the estimates that do not control for the unobserved candidate-district characteristics $P_{j c}$ are upwards biased. The effect of incumbent spending is, as in the cross-sectional setting, insignificant both in a statistical and practical sense. We see that the effects of the control variables are broadly speaking comparable to what we found earlier. The only exceptions are the effects for junior and senior government members, which are now strongly significant and negative. ${ }^{26}$

The results in column 2 correspond to a specification where campaign spending of challengers is allowed to differ by party (given that incumbent spending was found to be not significant, we keep imposing that the impact of this variable is invariant across parties). Column 2 shows that incumbent spending remains insignificant in this specification, but that challenger spending does have a significant effect for all parties except PC. The esti-

\footnotetext{
${ }^{26}$ None of the candidates have changed parties between the two elections, hence the impact of party indicators are not identified. Furthermore, government members standing for election in 1993 (resp. 1997) all belonged to the PS (resp. RPR and UDF), and $\Delta v$ tends to be positive for PS candidates and negative for RPR and UDF candidates (see Table A1). The difference in government membership dummies thus equal -1 for PS government members, +1 for RPR or UDF government members (and 0 in the majority of other cases), thereby explaining the negative effects we find for government members.
} 
mates range between 0.188 (other parties) to 0.085 (PC). Using a F-test, we cannot reject the hypothesis that the six coefficients are equal ( $\mathrm{p}$-value equals 0.2359 ). The conclusions regarding all other variables remain practically unchanged relatively to what was found in column 1.

\subsection{Robustness analysis}

This section presents two robustness checks. First we investigate whether endogenous sample selection is an important issue. Second we discuss the estimation results of our vote equation under the alternative assumption that voters primarily vote not for individual candidates but for parties.

A possible concern with the estimations reported in Table 6 is that they are based on candidates present in both elections: those who competed either only in 1993 or only in 1997 are excluded from the sample that produced the FD estimates. This selection may not be random and can result in a violation of the zero conditional mean assumption (conditional on being selected in the sample): $E\left(\Delta \xi_{j c} \mid \Delta X_{j c}, \Delta s_{j c}, j\right.$ present in 1993 and 1997) $\neq 0$. In this case the FD estimates would be biased. To account and test for endogenous sample selection one can for instance use the two-stage correction method introduced by Heckman (1979). However, this method cannot be implemented here because we do not have adequate data to estimate the participation decision of candidates (the first stage of Heckman's procedure). Indeed, for candidates present in just one election we only observe, by construction, the values of $X$ and $s$ prevailing in that election (i.e., the values are missing in the other election). In addition, there are no natural candidate variables that could act as determinants of the participation decision while satisfying an exclusion restriction at the same time. For these reasons we will not be able to formally check the robustness of our results to endogenous sample selection. Instead, we informally investigate the question by estimating (6) using the full data sets, and compare the estimates with those obtained using the sample of candidates present in both elections, which were reported in Table 5 . Column 1 of Table A5 lists the OLS estimation results of model (6) using all 5,104 candidates observed in the 1993 election (the sample size drops from 5,138 to 5,104 because 34 candidates received no votes in 1993). Compared to the restricted-sample estimates reported in column 1 of Table 5, we see that spending now has a significant effect not only for challengers but also for incumbents. The effect of incumbent spending remains small though (the point estimate is 0.064 in Table A5, and 0.029 in Table 5). The results regarding the control variables are comparable: the variables that are significant using the restricted sample remain significant when estimation is based on all candidates; some additional variables have turned significant but the magnitude of the estimates remains of the same order. Column 2 of Table A5 reports the results for the 1997 election using all 6,113 candidates standing for election in that year (84 candidates drop from the initial sample 
Table 5: Estimating the effect of campaign spending on vote shares (OLS)

\begin{tabular}{|c|c|c|}
\hline & 1993 & 1997 \\
\hline Spending challenger & $\begin{array}{c}0.365^{* * *} \\
(0.028)\end{array}$ & $\begin{array}{c}0.710^{* * *} \\
(0.050)\end{array}$ \\
\hline Spending incumbent & $\begin{array}{c}0.029 \\
(0.042)\end{array}$ & $\begin{array}{c}0.053 \\
(0.051)\end{array}$ \\
\hline Incumbent & $\begin{array}{c}1.343^{* * *} \\
(0.158)\end{array}$ & $\begin{array}{c}1.711^{* * *} \\
(0.146)\end{array}$ \\
\hline \multicolumn{3}{|l|}{ Local elective office: } \\
\hline Member of Municipal Council & $\begin{array}{c}0.349^{* * *} \\
(0.058)\end{array}$ & $\begin{array}{c}0.237^{* * *} \\
(0.052)\end{array}$ \\
\hline Member of Departmental Council (DC) & $\begin{array}{c}0.259^{* * *} \\
(0.063)\end{array}$ & $\begin{array}{c}0.150^{* * *} \\
(0.058)\end{array}$ \\
\hline President of DC & $\begin{array}{c}0.091 \\
(0.197)\end{array}$ & $\begin{array}{c}0.016 \\
(0.140)\end{array}$ \\
\hline Member of Regional Council (RC) & $\begin{array}{c}0.241^{* * *} \\
(0.050)\end{array}$ & $\begin{array}{c}0.090 \\
(0.056)\end{array}$ \\
\hline President of $\mathrm{RC}$ & $\begin{array}{c}0.232 \\
(0.333)\end{array}$ & $\begin{array}{l}-0.107 \\
(0.234)\end{array}$ \\
\hline Mayor & $\begin{array}{c}0.356^{* * *} \\
(0.063)\end{array}$ & $\begin{array}{c}0.270^{* * *} \\
(0.060)\end{array}$ \\
\hline Deputy Mayor & $\begin{array}{c}0.402^{* * *} \\
(0.084)\end{array}$ & $\begin{array}{c}0.319^{* * *} \\
(0.076)\end{array}$ \\
\hline Former representative of Assembly & $\begin{array}{c}0.063 \\
(0.107)\end{array}$ & $\begin{array}{c}0.333^{* * *} \\
(0.110)\end{array}$ \\
\hline Member of Senate & $\begin{array}{l}-0.120 \\
(0.137)\end{array}$ & $\begin{array}{c}0.021 \\
(0.132)\end{array}$ \\
\hline Senior member of government & $\begin{array}{c}-0.062 \\
(0.223)\end{array}$ & $\begin{array}{c}0.048 \\
(0.232)\end{array}$ \\
\hline Junior member of government & $\begin{array}{l}-0.144 \\
(0.186)\end{array}$ & $\begin{array}{l}-0.183 \\
(0.129)\end{array}$ \\
\hline Political party leadership & $\begin{array}{c}0.054 \\
(0.061)\end{array}$ & $\begin{array}{c}0.068 \\
(0.063)\end{array}$ \\
\hline \multicolumn{3}{|l|}{ Party affiliation: } \\
\hline FN & $\begin{array}{c}1.227^{* * *} \\
(0.066)\end{array}$ & $\begin{array}{c}0.675^{* * *} \\
(0.080)\end{array}$ \\
\hline $\mathrm{PC}$ & $\begin{array}{c}0.586^{* * *} \\
(0.062)\end{array}$ & $\begin{array}{c}0.445^{* * *} \\
(0.071)\end{array}$ \\
\hline PS & $\begin{array}{c}0.589^{* * *} \\
(0.098)\end{array}$ & $\begin{array}{c}0.851^{* * *} \\
(0.089)\end{array}$ \\
\hline RPR & $\begin{array}{c}0.939^{* * *} \\
(0.107)\end{array}$ & $\begin{array}{c}0.607^{* * *} \\
(0.091)\end{array}$ \\
\hline UDF & $\begin{array}{c}0.956^{* * *} \\
(0.103)\end{array}$ & $\begin{array}{c}0.606^{* * *} \\
(0.094)\end{array}$ \\
\hline Observations & 1643 & 1643 \\
\hline$R^{2}$ & 0.855 & 0.858 \\
\hline
\end{tabular}


Table 6: Estimating the effect of campaign spending on vote shares (FD)

\begin{tabular}{|c|c|c|}
\hline & (1) & (2) \\
\hline Spending challenger & $\begin{array}{c}0.133^{* * *} \\
(0.022)\end{array}$ & \\
\hline Spending challenger FN & & $\begin{array}{c}0.165^{* * *} \\
(0.027)\end{array}$ \\
\hline Spending challenger PC & & $\begin{array}{c}0.085 \\
(0.060)\end{array}$ \\
\hline Spending challenger PS & & $\begin{array}{c}0.149^{* * *} \\
(0.058)\end{array}$ \\
\hline Spending challenger RPR & & $\begin{array}{c}0.114^{* * *} \\
(0.031)\end{array}$ \\
\hline Spending challenger UDF & & $\begin{array}{c}0.106^{* * *} \\
(0.033)\end{array}$ \\
\hline Spending challenger other party & & $\begin{array}{c}0.188^{* * *} \\
(0.045)\end{array}$ \\
\hline Spending incumbent & $\begin{array}{c}0.013 \\
(0.027)\end{array}$ & $\begin{array}{c}0.017 \\
(0.029)\end{array}$ \\
\hline Incumbent & $\begin{array}{c}0.276^{* * *} \\
(0.096)\end{array}$ & $\begin{array}{l}0.235^{* *} \\
(0.104)\end{array}$ \\
\hline \multicolumn{3}{|l|}{ Local elective office: } \\
\hline Member of Municipal Council & $\begin{array}{l}0.115^{* *} \\
(0.048)\end{array}$ & $\begin{array}{l}0.112^{* *} \\
(0.048)\end{array}$ \\
\hline Member of Departmental Council (DC) & $\begin{array}{l}-0.030 \\
(0.094)\end{array}$ & $\begin{array}{l}-0.030 \\
(0.091)\end{array}$ \\
\hline President of DC & $\begin{array}{c}0.254 \\
(0.223)\end{array}$ & $\begin{array}{c}0.261 \\
(0.231)\end{array}$ \\
\hline Member of Regional Council (RC) & $\begin{array}{c}0.050 \\
(0.069)\end{array}$ & $\begin{array}{c}0.060 \\
(0.070)\end{array}$ \\
\hline President of $\mathrm{RC}$ & $\begin{array}{l}-0.360^{*} \\
(0.205)\end{array}$ & $\begin{array}{l}-0.296 \\
(0.182)\end{array}$ \\
\hline Mayor & $\begin{array}{l}0.145^{* *} \\
(0.059)\end{array}$ & $\begin{array}{l}0.148^{* *} \\
(0.059)\end{array}$ \\
\hline Deputy Mayor & $\begin{array}{l}0.151^{* *} \\
(0.073)\end{array}$ & $\begin{array}{l}0.151^{* *} \\
(0.072)\end{array}$ \\
\hline Former representative of Assembly & $\begin{array}{l}0.110^{*} \\
(0.061)\end{array}$ & $\begin{array}{c}0.088 \\
(0.062)\end{array}$ \\
\hline Member of Senate & $\begin{array}{c}0.186 \\
(0.117)\end{array}$ & $\begin{array}{c}0.189 \\
(0.137)\end{array}$ \\
\hline Junior member government & $\begin{array}{c}-0.312^{* * *} \\
(0.084)\end{array}$ & $\begin{array}{c}-0.295^{* * *} \\
(0.083)\end{array}$ \\
\hline Senior member government & $\begin{array}{c}-0.283^{* *} \\
(0.137)\end{array}$ & $\begin{array}{c}-0.278^{* *} \\
(0.134)\end{array}$ \\
\hline Political party leadership & $\begin{array}{c}0.007 \\
(0.050)\end{array}$ & $\begin{array}{c}0.013 \\
(0.051)\end{array}$ \\
\hline Observations & 1642 & 1642 \\
\hline$R^{2}$ & 0.370 & 0.375 \\
\hline
\end{tabular}


because they obtained no votes in 1997). Again, campaign spending is now significant for incumbents but the estimated impact remains small. Furthermore, as for the 1993 election, some additional control variables become significant but the point estimates are in most cases similar to the ones reported in column 2 of Table 5 . The overall message of Table A5 is that although estimation based on the complete samples allows to estimate most parameters with more precision (rendering some variables significant), the conclusions do not fundamentally change relatively to those obtained obtained with the restricted samples, suggesting that endogenous sample selection is not an important issue.

Unlike the French presidential elections, where the same set of candidates compete with each other in all electoral districts, the sets of candidates in legislative elections are district-specific. In legislative elections it may therefore be more difficult and costly for voters to become precisely informed about the precise profiles of candidates competing in their electoral district. Voters may then be inclined to make their electoral choices solely on the basis of the standpoints of parties expressed at the national level, and not on the basis of the specific opinions or features of the candidates among which they choose in the district. Voters would in this case vote primarily for parties rather than for candidates. This alternative way of viewing voter decisions does not fundamentally alter the model presented in Section 5, only the interpretations of the parameters slightly change. $U_{i j c t}$ now designates the utility that voter $i$ gets from voting for party $j$ in district $c$ and election $t$. The parameter $\gamma$ measures the effect of the fact that party $j$ fields a candidate who is say the incumbent or the mayor. Our key parameter, $\gamma$, here measures the effect of the total amount of money spent by the candidate of party $j, \xi_{j c t}$ is an unobserved local demand shock affecting party $j$, and $\epsilon_{i j c t}$ is the idiosyncratic error term influencing the utility of choosing party $j$. The interpretation of $\alpha_{c t}$ remains unchanged. Importantly, $P_{j c}$ now captures the unobserved attractiveness of party $j$ in district $c$, or the unobserved taste of voters for this party. As before, we can eliminate $P_{j c}$ by applying a first-difference transformation to equation (6). For each $c$, we apply the transformation to party $j$ if this party is fielding a candidate in both elections in this constituency. Note that unlike before, the candidate in the two elections is no longer necessarily the same person. The FD estimates are presented in Table A6, in the same way as Table 6. There are now 1,427 observations. ${ }^{27}$ Focussing on the estimates of $\beta$, we see in column 1 that, like in Table 6 , spending is only significant for challengers but not for incumbents. The effect of challenger spending remains of the same order (0.133 in Table 6 and 0.171 in Table A6). Column 2 shows that incumbent spending remains insignificant once we allow challenger spending to be party-specific. The effects of challenger spending by party are comparable to those in column 2 of Table 6 , suggesting that our main results are robust to the change in the

\footnotetext{
${ }^{27}$ For simplicity, we have aggregated here all other parties than FN, PC, PS, RPR and UDF into a fictitious one. As a result, in each constituency we cannot have more than one candidate linked to this fictitious party, which reduces mechanically the number of observations relatively to the previous approach.
} 
underlying assumption on voter behavior.

\section{Conclusion}

This paper has addressed an old question in the political economics literature using a novel empirical approach. Our strategy to identify and estimate the impact of campaign spending on election outcomes does not use instrumental variables (the typical approach adopted so far in the literature), but instead exploits campaign financing reforms. We use the reforms introduced in France in the mid 1990s. Using data on two consecutive legislative elections held in France, one before the introduction of the new laws (1993) and one after the introduction (1997), we find that the reforms affected the spending patterns of candidates. Those from the far-left and far-right ( $\mathrm{PC}$ and $\mathrm{FN})$ strongly increased their campaign budgets between the two elections (essentially they benefitted from the more generous reimbursement scheme of personal investments), while those from the centre-left and centre-right (PS, UDF, RPR) substantially reduced their expenses (they were harmed by the lower spending limits and the banning of contributions from legal persons). Overall, the spending spread across candidates of the five main parties is substantially smaller in 1997 compared to 1993. More importantly, for our empirical strategy, the difference in spending across the two elections is due to the modifications in the campaign financing rules, and not the consequence of strategic choices of candidates or the parties to which they belong.

To estimate the impact of campaign spending, we use a model à la Berry (1994), initially introduced to analyze consumer purchases in differentiated-product markets. The framework is easily transposed to an election setting (consumers become voters, products become candidates, and markets become electoral districts), and ideally fitted to account for the fact that relatively large numbers of candidates compete in the French legislative elections. The model implies that the candidate's vote share divided by the abstention rate only depends on the characteristics of this candidate and features of the electoral district in which he competes. Using data on candidates present in both elections, we estimate the vote equation in first differences to eliminate the impact of unobserved popularity determinants. The only condition required to obtain unbiased estimators is that the difference in spending is exogenous, a natural assumption given that spending profiles over time were affected by the law modifications. We find a statistically significant effect for campaign spending, but only for challengers. The impact for challengers is, however, weak in economic terms: a challenger with a first-round vote share of $30 \%$ who increases spending by FFr100,000 can expect his share to increase by only 2.8 percentage points. The effect of challenger spending is found to be the same for the different parties that participate in the French legislative elections. 


\section{References}

Abramowitz, A. I. (1988): "Explaining Senate election outcomes," American Political Science Review, 82(2), 385-403.

(1991): "Incumbency, campaign spending, and the decline of competition in US House elections," Journal of Politics, 53(1), 34-56.

BERry, S. T. (1994): "Estimating discrete-choice models of product differentiation," RAND Journal of Economics, 25(2), 242-262.

Cox, G. W., And M. F. Thies (2000): "How Much Does Money Matter? Buying Votes in Japan, 1967-1990," Comparative Political Studies, 33(1), 37-57.

Da Silveira, B. S., And J. M. De Mello (2011): "Campaign advertising and election outcomes: Quasi-natural experiment evidence from gubernatorial elections in Brazil," Review of Economic Studies, 78(2), 590-612.

Durante, R., and E. Gutierrez (2014): "Political advertising and voting intentions: Evidence from exogenous variation in ads viewership," Working Paper Sciences Po.

Erikson, R. S., and T. R. Palfrey (1998): "Campaign spending and incumbency: an alternative simultaneous equations approach," Journal of Politics, 60(2), 355-373.

Foucault, M., And A. FrançOis (2005): "Le rendement des dépenses électorales en France," Revue Économique, 56(5), 1125-1143.

François, A., And N. Sauger (2006): "Groupes d'intérêt et financement de la vie politique en France," Revue Française de Science Politique, 56(2), 227-254.

Gerber, A. S. (1998): "Estimating the effect of campaign spending on Senate election outcomes using instrumental variables," American Political Science Review, 92(2), 401411.

Gerber, A. S., J. G. Gimpel, D. P. Green, and D. R. Shaw (2011): "How large and long-lasting are the persuasive effects of televised campaign ads? Results from a randomized field experiment," American Political Science Review, 105(1), 135-150.

Glantz, S. A., A. I. Abramowitz, and M. P. Burkart (1976): "Election outcomes: Whose money matters?," Journal of Politics, 38(4), 1033-1038.

Heckman, J. J. (1979): "Sample bias as a specification error," Econometrica, 47(1), $153-161$.

JACOBSOn, G. C. (1978): "The effects of campaign spending in congressional elections," American Political Science Review, 72(2), 469-491. 
(2006): "Measuring campaign spending effects in U.S. House elections," in Capturing campaign effects, ed. by R. G. C. Johnston, and H. E. Brady, pp. 199-220. The University of Michigan Press.

LEVITT, S. D. (1994): "Using repeat challengers to estimate the effect of campaign spending on election outcomes in the US House," Journal of Political Economy, 102(4), 777798.

Milligan, K., and M. RekKas (2008): "Campaign spending limits, incumbent spending, and election outcomes," Canadian Journal of Economics, 41(4), 1351-1374.

PAlda, F., AND K. PAldA (1998): "The impact of campaign expenditures on political competition in the French legislative elections of 1993," Public Choice, 94(1-2), 157-174.

Pattie, C. J., R. J. Johnston, and E. A. Fieldhouse (1995): "Winning the local vote: The effectiveness of constituency campaign spending in Great Britain, 1983-1992," American Political Science Review, 89(4), 969-983.

REKKAs, M. (2007): "The impact of campaign spending on votes in multiparty elections," Review of Economics and Statistics, 89(3), 573-585.

Stratmann, T. (2005): "Some talk: Money in politics. A (partial) review of the literature," Public Choice, 124(1/2), 135-156.

Welch, W. P. (1981): "Money and votes: A simultaneous equation model," Public Choice, 36(2), 209-234. 


\section{A Additional figures}

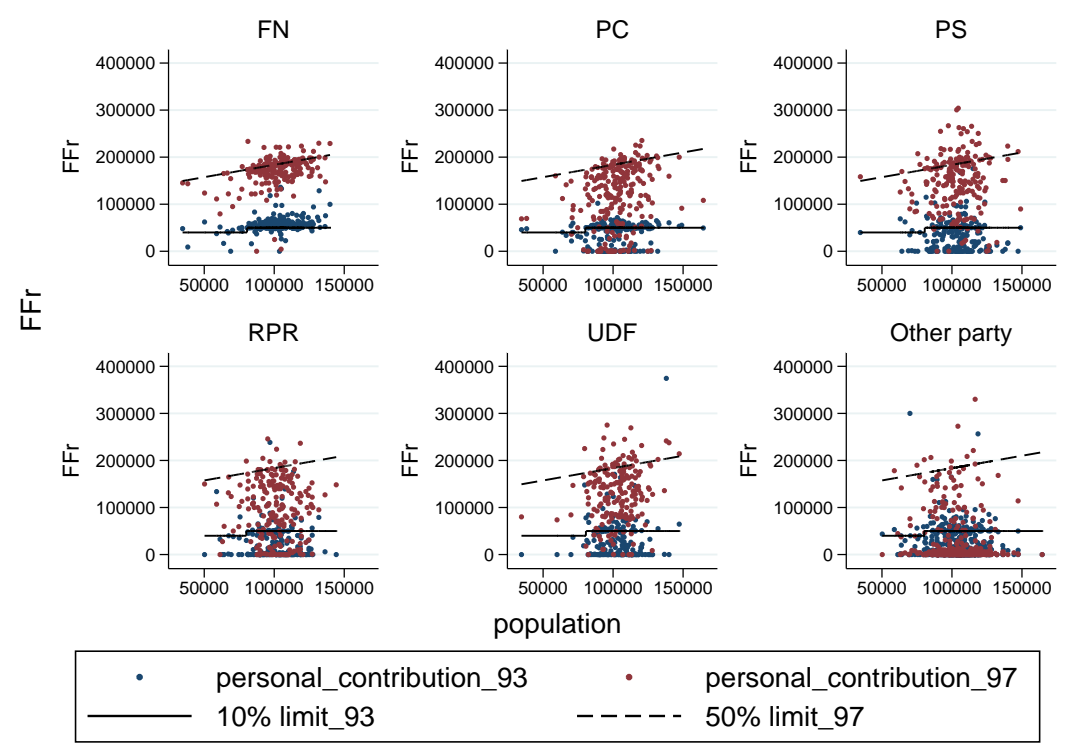

Figure 2: Personal spending of candidates in 1993 and 1997 by party 


\section{B Additional tables}

Table A1: First-round score and number of representatives

\begin{tabular}{lcccc}
\hline & \multicolumn{2}{c}{$\underline{\underline{1993}}$} & \multicolumn{1}{l}{$\underline{\underline{197}}$} \\
Party & Score (\%) & Representatives & Score (\%) & Representatives \\
\hline FN & 12.42 & 0 & 14.94 & 1 \\
PC & 9.19 & 23 & 9.94 & 35 \\
PS & 17.40 & 57 & 23.53 & 255 \\
RPR & 19.83 & 257 & 15.70 & 139 \\
UDF & 18.64 & 215 & 14.21 & 112 \\
\hline Notes: The columns headed 'Score' give the sum of first-round votes received by \\
each party divided by the total number of first-round votes at the national level. \\
The columns headed 'Representatives' give the number of seats obtained by each \\
party in the National Assembly. Source: French Interior Ministry.
\end{tabular}

Table A2: Population and spending limit per constituency

\begin{tabular}{|c|c|c|c|c|c|}
\hline & Obs. & Mean & S.D. & Min & $\operatorname{Max}$ \\
\hline Population in 1990 & 555 & 102,009 & 15,091 & 34,577 & 164,472 \\
\hline Spending limit in 1993 & 555 & 494,775 & 22,274 & 400,000 & 500,000 \\
\hline Spending limit in 1997 & 555 & 369,610 & 15,845 & 298,806 & 435,196 \\
\hline
\end{tabular}


Table A3: Determinants of sources of funding

\begin{tabular}{|c|c|c|}
\hline & $\begin{array}{c}(1) \\
\text { Donations from legal persons }\end{array}$ & $\begin{array}{c}(2) \\
\text { Difference in personal spending }\end{array}$ \\
\hline Incumbent & $\begin{array}{c}33,714^{* * *} \\
(6,984)\end{array}$ & $\begin{array}{c}18,271^{* * *} \\
(5,153)\end{array}$ \\
\hline \multicolumn{3}{|l|}{ Local elective office: } \\
\hline Member of Municipal Council (MC) & $\begin{array}{c}2,037 \\
(2,520)\end{array}$ & $\begin{array}{c}10,374^{* *} \\
(4,042)\end{array}$ \\
\hline Member of Departmental Council (DC) & $\begin{array}{l}9,176^{*} \\
(5,523)\end{array}$ & $\begin{array}{l}8,738^{*} \\
(4,710)\end{array}$ \\
\hline President of DC & $\begin{array}{l}-19,437 \\
(30,061)\end{array}$ & $\begin{array}{l}-19,530 \\
(15,716)\end{array}$ \\
\hline Member of Regional Council (RC) & $\begin{array}{c}2,962 \\
(3,436)\end{array}$ & $\begin{array}{l}9,268^{* *} \\
(4,040)\end{array}$ \\
\hline President of $\mathrm{RC}$ & $\begin{array}{l}-30,675 \\
(32,205)\end{array}$ & $\begin{array}{c}26,029 \\
(28,619)\end{array}$ \\
\hline Mayor & $\begin{array}{c}57,834^{* * *} \\
(5,367)\end{array}$ & $\begin{array}{c}18,866^{* * *} \\
(4,, 727)\end{array}$ \\
\hline Deputy Mayor & $\begin{array}{c}33,306^{* * *} \\
(5,384)\end{array}$ & $\begin{array}{l}11,189^{*} \\
(6,139)\end{array}$ \\
\hline Former representative & $\begin{array}{l}12,744 \\
(9,357)\end{array}$ & $\begin{array}{l}-4,175 \\
(8,026)\end{array}$ \\
\hline Member of Senate & $\begin{array}{c}1,510 \\
(17,486)\end{array}$ & $\begin{array}{c}88,266^{* * *} \\
(9,550)\end{array}$ \\
\hline Minister & $\begin{array}{c}107,004^{* * *} \\
(36,571)\end{array}$ & $\begin{array}{c}-1,696 \\
(16,596)\end{array}$ \\
\hline Deputy minister & $\begin{array}{c}9,551 \\
(34,847)\end{array}$ & $\begin{array}{c}8,773 \\
(13,447)\end{array}$ \\
\hline Political party leadership & $\begin{array}{c}13,389^{* *} \\
(5,287)\end{array}$ & $\begin{array}{c}3,194 \\
(4,620)\end{array}$ \\
\hline \multicolumn{3}{|l|}{ Party affiliation: } \\
\hline $\mathrm{FN}$ & $\begin{array}{c}-8,044^{* * *} \\
(1,223)\end{array}$ & $\begin{array}{c}103,040^{* * *} \\
(3,022)\end{array}$ \\
\hline $\mathrm{PC}$ & $\begin{array}{c}-8,466^{* * *} \\
(2,306)\end{array}$ & $\begin{array}{c}65,780^{* * *} \\
(4,013)\end{array}$ \\
\hline PS & $\begin{array}{c}30,426^{* * *} \\
(4,522)\end{array}$ & $\begin{array}{c}76,787^{* * *} \\
(6,213)\end{array}$ \\
\hline $\mathrm{RPR}$ & $\begin{array}{c}90,109^{* * * *} \\
(7,268)\end{array}$ & $\begin{array}{c}43,520^{* * *} \\
(6,589)\end{array}$ \\
\hline UDF & $\begin{array}{c}65,896^{* * *} \\
(7,505)\end{array}$ & $\begin{array}{c}68,023^{* * *} \\
(6,208)\end{array}$ \\
\hline Constant & $\begin{array}{c}5,196^{* * *} \\
(589)\end{array}$ & $\begin{array}{l}-2,025 \\
(1,575)\end{array}$ \\
\hline Observations & 5,138 & 1,644 \\
\hline 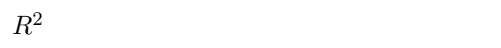 & 0.421 & 0.441 \\
\hline
\end{tabular}


Table A4: Donations from legal persons

\begin{tabular}{|c|c|c|c|c|c|c|}
\hline & $\mathrm{FN}$ & $\mathrm{PC}$ & PS & RPR & UDF & Other parties \\
\hline & \multicolumn{6}{|c|}{ Candidates present in 1993} \\
\hline Fraction of recipients & $9.7 \%$ & $25.2 \%$ & $71.5 \%$ & $93.1 \%$ & $87.4 \%$ & $18.1 \%$ \\
\hline Average donation & 1,220 & 16,822 & 86,319 & 143,129 & 121,776 & 10,103 \\
\hline \multirow[t]{2}{*}{ Observations } & 554 & 555 & 522 & 303 & 293 & 2,911 \\
\hline & \multicolumn{6}{|c|}{ Candidates present in 1993 and 1997} \\
\hline Fraction of recipients & $10.8 \%$ & $29.2 \%$ & $80.9 \%$ & $92.5 \%$ & $87.2 \%$ & $18.3 \%$ \\
\hline Average donation & 1,736 & 23,806 & 121,174 & 140,808 & 123,008 & 16,036 \\
\hline Observations & 249 & 243 & 215 & 214 & 195 & 531 \\
\hline
\end{tabular}


Table A5: Estimation of model (6) using complete samples

\begin{tabular}{|c|c|c|}
\hline & 1993 & 1997 \\
\hline Spending challenger & $\begin{array}{c}0.440^{* * *} \\
(0.018)\end{array}$ & $\begin{array}{c}0.864^{* * *} \\
(0.022)\end{array}$ \\
\hline Spending incumbent & $\begin{array}{c}0.064^{* * *} \\
(0.024)\end{array}$ & $\begin{array}{c}0.118^{* * *} \\
(0.036)\end{array}$ \\
\hline Incumbent & $\begin{array}{c}1.366^{* * *} \\
(0.089)\end{array}$ & $\begin{array}{c}1.749^{* * *} \\
(0.097)\end{array}$ \\
\hline \multicolumn{3}{|l|}{ Local elective office: } \\
\hline Member of Municipal Council & $\begin{array}{c}0.447^{* * *} \\
(0.038)\end{array}$ & $\begin{array}{c}0.290^{* * *} \\
(0.032)\end{array}$ \\
\hline Member of Departmental Council (DC) & $\begin{array}{c}0.257^{* * *} \\
(0.035)\end{array}$ & $\begin{array}{c}0.154^{* * *} \\
(0.036)\end{array}$ \\
\hline President of DC & $\begin{array}{c}0.309^{* * *} \\
(0.089)\end{array}$ & $\begin{array}{c}0.142 \\
(0.088)\end{array}$ \\
\hline Member of Regional Council (RC) & $\begin{array}{c}0.271^{* * *} \\
(0.036)\end{array}$ & $\begin{array}{c}0.173^{* * *} \\
(0.034)\end{array}$ \\
\hline President of $\mathrm{RC}$ & $\begin{array}{c}0.309 \\
(0.189)\end{array}$ & $\begin{array}{l}-0.214 \\
(0.150)\end{array}$ \\
\hline Mayor & $\begin{array}{c}0.392^{* * *} \\
(0.037)\end{array}$ & $\begin{array}{c}0.338^{* * *} \\
(0.033)\end{array}$ \\
\hline Deputy Mayor & $\begin{array}{c}0.457^{* * *} \\
(0.047)\end{array}$ & $\begin{array}{c}0.346^{* * *} \\
(0.044)\end{array}$ \\
\hline Former representative of Assembly & $\begin{array}{c}0.086 \\
(0.072)\end{array}$ & $\begin{array}{l}0.130^{* *} \\
(0.059)\end{array}$ \\
\hline Member of Senate & $\begin{array}{c}0.164 \\
(0.178)\end{array}$ & $\begin{array}{c}0.113 \\
(0.155)\end{array}$ \\
\hline Senior member of government & $\begin{array}{c}-0.284^{*} \\
(0.149)\end{array}$ & $\begin{array}{c}0.197 \\
(0.129)\end{array}$ \\
\hline Junior member of government & $\begin{array}{l}-0.070 \\
(0.213)\end{array}$ & $\begin{array}{c}0.163 \\
(0.217)\end{array}$ \\
\hline Political party leadership & $\begin{array}{l}0.098^{* *} \\
(0.040)\end{array}$ & $\begin{array}{c}0.128^{* * *} \\
(0.043)\end{array}$ \\
\hline \multicolumn{3}{|l|}{ Party affiliation: } \\
\hline $\mathrm{FN}$ & $\begin{array}{c}1.352^{* * *} \\
(0.030)\end{array}$ & $\begin{array}{c}0.669^{* * *} \\
(0.038)\end{array}$ \\
\hline $\mathrm{PC}$ & $\begin{array}{c}0.677^{* * *} \\
(0.030)\end{array}$ & $\begin{array}{c}0.464^{* * *} \\
(0.033)\end{array}$ \\
\hline PS & $\begin{array}{c}0.658^{* * *} \\
(0.042)\end{array}$ & $\begin{array}{c}0.922^{* * *} \\
(0.046)\end{array}$ \\
\hline RPR & $\begin{array}{c}0.838^{* * *} \\
(0.058)\end{array}$ & $\begin{array}{c}0.609^{* * *} \\
(0.061)\end{array}$ \\
\hline UDF & $\begin{array}{c}0.759^{* * *} \\
(0.060)\end{array}$ & $\begin{array}{c}0.618^{* * *} \\
(0.064)\end{array}$ \\
\hline Observations & 5104 & 6113 \\
\hline$R^{2}$ & 0.708 & 0.733 \\
\hline
\end{tabular}


Table A6: Voting for parties

\begin{tabular}{|c|c|c|}
\hline & $(1)$ & $(2)$ \\
\hline Spending challenger & $\begin{array}{c}0.171^{* * *} \\
(0.028)\end{array}$ & \\
\hline Spending challenger FN & & $\begin{array}{c}0.112^{* * *} \\
(0.032)\end{array}$ \\
\hline Spending challenger $\mathrm{PC}$ & & $\begin{array}{c}0.016 \\
(0.069)\end{array}$ \\
\hline Spending challenger PS & & $\begin{array}{l}0.116^{*} \\
(0.066)\end{array}$ \\
\hline Spending challenger RPR & & $\begin{array}{c}0.116^{* * *} \\
(0.037)\end{array}$ \\
\hline Spending challenger UDF & & $\begin{array}{c}0.118^{* * *} \\
(0.041)\end{array}$ \\
\hline Spending challenger other party & & $\begin{array}{c}0.401^{* * *} \\
(0.078)\end{array}$ \\
\hline Spending incumbent & $\begin{array}{l}-0.010 \\
(0.029)\end{array}$ & $\begin{array}{c}0.018 \\
(0.030)\end{array}$ \\
\hline Incumbent & $\begin{array}{c}0.449^{* * *} \\
(0.133)\end{array}$ & $\begin{array}{c}0.204 \\
(0.155)\end{array}$ \\
\hline \multicolumn{3}{|l|}{ Local elective office: } \\
\hline Member of Municipal Council & $\begin{array}{c}0.095^{* *} \\
(0.040)\end{array}$ & $\begin{array}{c}0.093^{\text {** }} \\
(0.039)\end{array}$ \\
\hline Member of Departmental Council (DC) & $\begin{array}{c}0.079 \\
(0.108)\end{array}$ & $\begin{array}{c}0.054 \\
(0.098)\end{array}$ \\
\hline President of DC & $\begin{array}{c}0.123 \\
(0.257)\end{array}$ & $\begin{array}{c}0.120 \\
(0.257)\end{array}$ \\
\hline Member of Regional Council (RC) & $\begin{array}{c}0.088 \\
(0.071)\end{array}$ & $\begin{array}{c}0.085 \\
(0.067)\end{array}$ \\
\hline President of $\mathrm{RC}$ & $\begin{array}{c}0.038 \\
(0.217)\end{array}$ & $\begin{array}{c}0.057 \\
(0.255)\end{array}$ \\
\hline Mayor & $\begin{array}{c}0.233^{* * *} \\
(0.068)\end{array}$ & $\begin{array}{c}0.208^{* * *} \\
(0.063)\end{array}$ \\
\hline Deputy Mayor & $\begin{array}{l}0.130^{*} \\
(0.066)\end{array}$ & $\begin{array}{c}0.139^{* *} \\
(0.064)\end{array}$ \\
\hline Former representative of Assembly & $\begin{array}{l}0.141^{*} \\
(0.072)\end{array}$ & $\begin{array}{c}0.101 \\
(0.071)\end{array}$ \\
\hline Member of Senate & $\begin{array}{c}0.091 \\
(0.127)\end{array}$ & $\begin{array}{l}0.223^{*} \\
(0.130)\end{array}$ \\
\hline Junior member government & $\begin{array}{c}-0.278^{* * *} \\
(0.099)\end{array}$ & $\begin{array}{c}-0.248^{* *} \\
(0.101)\end{array}$ \\
\hline Senior member government & $\begin{array}{c}-0.405^{* *} \\
(0.172)\end{array}$ & $\begin{array}{l}-0.320^{*} \\
(0.166)\end{array}$ \\
\hline Political party leadership & $\begin{array}{c}0.046 \\
(0.054)\end{array}$ & $\begin{array}{c}0.050 \\
(0.054)\end{array}$ \\
\hline $\begin{array}{l}\text { Observations } \\
R^{2}\end{array}$ & $\begin{array}{l}1427 \\
0.530\end{array}$ & $\begin{array}{l}1427 \\
0.570\end{array}$ \\
\hline $\begin{array}{l}\text { Notes: Reported are the OLS estimation results } \\
\text { vote for parties rather than for candidates (see } \\
\text { entries are the estimates and in parentheses are th } \\
\text { level. }{ }^{*} p<0.10,{ }^{* *} p<0.05,{ }^{* * *} p<0.01\end{array}$ & $\begin{array}{l}\text { lel (7) unde } \\
\text { text for a } \\
\text { dard errors }\end{array}$ & $\begin{array}{l}\text { n that voter: } \\
\text { ation). Mair } \\
\text { constituency }\end{array}$ \\
\hline
\end{tabular}

